\title{
Foreign Experience and CEO Compensation
}

\author{
Martin Conyon $^{\mathrm{a}, \mathrm{b}} \quad$ Lars Helge Haß ${ }^{\mathrm{c}} \quad$ Skrålan Vergauwe ${ }^{\mathrm{c}} \quad$ Zhifang Zhangd,*
}

* Corresponding author

${ }^{a}$ Bentley University, Massachusetts, MA 02452, USA

${ }^{b}$ Senior Fellow, the Wharton School, University of Pennsylvania, Philadelphia, PA 19104, USA

${ }^{c}$ Lancaster University Management School, Lancaster University, Lancaster, LA1 4YX, United Kingdom

${ }^{d}$ Essex Business School, University of Essex, Colchester, CO4 3SQ, United Kingdom

Email addresses: mconyon@bentley.edu (M.J. Conyon), 1.h.hass@lancaster.ac.uk (L.H. Haß), s.vergauwe@lancaster.ac.uk (S. Vergauwe), z.zhang@essex.ac.uk (Z.Zhang). 


\title{
Foreign Experience and CEO Compensation
}

\begin{abstract}
This paper investigates the relationship between a CEO's foreign experience and CEO compensation. Our analysis is based on the constituent firms of the UK FTSE 350 index from 1999 to 2015. We find that foreign CEOs and national CEOs with foreign working experience receive significantly higher levels of total compensation compared to similar UK CEOs without such characteristics. The results are robust to the endogenous CEO selection using propensity score matching methods, as well as other modelling approaches. Our results show that pay premiums are attributable to the specialized foreign expertise and foreign networks of CEOs, which stem from foreign experience rather than broader general managerial skills.
\end{abstract}

\section{Highlights:}

- We study the effect of CEO foreign experience on CEO total compensation.

- $\mathrm{CEO}$ foreign experience is associated with higher CEO total compensation.

- The impact is attributable to specialized foreign expertise and foreign networks of CEOs.

Keywords: Foreign experience, corporate governance, executive compensation, international business

JEL Classification: G3, G34, F23 


\section{Introduction}

The globalization process is having a profound effect on product and labor markets, and increasingly on CEO labor markets (Carpenter, Sanders, and Gregersen, 2000; Osawa and Wong, 2015). Previous research overwhelmingly focuses on how CEO foreign experience affects organizational behavior and outcomes (such as firm profitability). Little attention has been paid to how CEOs themselves benefit from enhanced foreign experience. CEOs with foreign experience are potentially highly valuable to the firm. One hypothesis is that CEOs with international experience possess valuable foreign knowledge and access to networks that increase the firm's competitive advantage in the global market (e.g., Athanassiou and Nigh, 2005; Blomstermo et al., 2004; Useem 1984; Piaskowska and Trojanowski, 2014; Sambharya, 1996). The corollary is that the CEOs' own market value increases as well. However, critics of this claim assert that it is the CEOs' general managerial ability that is more important than foreign experience, and that international complexity can be managed through regional managers or local consultants (Carpenter, Sanders, and Gregersen, 2000). The tension between these competing perspectives, therefore, warrants an empirical investigation into the private returns to $\mathrm{CEO}$ from their foreign experience exposure. Specifically, this paper addresses the central research question: Do CEOs earn a compensation premium from foreign experience. Specifically, we test whether foreign CEOs or CEOs with significant foreign managerial experience have higher pay compared to similarly situated domestic CEOs.

Our paper blends two important streams of research in the extant literature. First, one stream connects CEO characteristics, and especially foreign experience, to organizational behavior and outcomes. One claim is that more foreign experience enhances firm performance. Largely, this stream neglects the potential private benefits to the CEOs 
themselves focusing instead on the returns to the enterprise (Cumming et al., 2017; Estélyi and Nisar, 2016; Nielsen and Nielsen, 2013; Piaskowska and Trojanowski, 2014). Second, there is a large stream of literature looking at the determinants of CEO compensation (Brockman, Lee, and Salas, 2016; Bryan, Nash, and Patel, 2015 Burns, Jindra, and Minnick, 2017). The research on international CEO pay focuses on comparing executive compensation across countries, but overlooks the potential influence of CEOs' prior experience in foreign countries on own CEO pay (Conyon et al., 2013; Conyon, Peck, and Sadler, 2009; Fernandes et al., 2013). By focusing precisely on the private returns to CEO foreign experience, this paper fills an important gap in the extant literature.

The theoretical motivation of the paper is motivated by and combines upper echelons (Hambrick and Mason, 1984) and resource dependence theory (Salancik and Pfeffer, 1978). It is hypothesized that firms that hire seasoned international CEOs are inclined to engage in foreign markets, and that CEOs with foreign experience provide their firms with a competitive advantage by providing them with both social capital (i.e. foreign networks) and human capital (i.e. foreign knowledge). Foreign experience is valuable as it is both nonsubstitutable and non-inimitable (Barney, 1991; Carpenter, Sanders and Gregersen, 2001; Daily, Certo, and Dalton, 2000; Sambharya, 1996; Sullivan, 1994). The trend for globalization also suggests that demand for CEOs with foreign experience will continue to increase, placing upward pressure on CEOs' compensation. Firms seeking to hire CEOs with such foreign experience are therefore willing to offer a compensation premium. Firms' levels of internationalization may also affect CEOs' total compensation, because CEOs' foreign experience might be more important and better realized in firms with higher levels of international dependence. Therefore, it is likely that CEOs' foreign experience will be positively associated with total CEO compensation, and that the effect of CEOs' foreign experience will be stronger as firms' level of internationalization increases. 
The UK is an ideal research context for our study. First, UK firms have a higher proportion of foreign CEOs (around 17 per cent), with more diverse nationalities than other countries, ${ }^{1}$ providing ample sample variation to test the hypotheses. Second, the level of mandated executive compensation disclosure is higher in the UK than in other European countries. It is comparable to the high disclosure standards pertaining to the US market (Vander Bauwhede and Willekens, 2008). Therefore, the UK provides the necessary highquality CEO compensation data. Third, in terms of global orientation, the UK holds the top position among all European Union countries for both out-bound acquirers and in-bound target markets, second only to the US worldwide (Allen and Overy, 2015). The sample of firms we investigate, therefore, provides sufficient firm and time-series observations, as well as maximizes the potential implications of the study. Last but not the least, our research design focuses on a single country in order to avoid the correlated omitted variable problems of multi-country studies, involving legal, regulatory, political, cultural and economic factors.

Our study focuses only on CEOs. This is because CEOs provide the most visible signals to shareholders, and they differ significantly from other top managers on a number of dimensions, including corporate influences, domestic influences and self-concepts (Daily, Certo, and Dalton, 2000; Norburn, 1989). There is also an implicit assumption that power and key decision-making authority are concentrated in the hands of CEOs (Herrmann and Datta, 2002). Our research design is therefore consistent with these prior studies.

\footnotetext{
${ }^{1}$ For example, 0.4 per cent of directors are of foreign nationality in China between 1999 and 2009 (Giannetti, Liao, and Yu, 2015), whereas 8.3 per cent of directors are from outside Nordic countries in 2008 (Oxelheim et al., 2013). In comparison, the average proportions of foreign CEOs in the US, France and Germany for the same sample period from 2003 to 2011, calculated from BoardEx data, are two per cent, six per cent and 10 per cent respectively. In addition, foreign CEOs in China are manually identified for this study, based on data from CSMAR, revealing an average of 0.5 per cent.
} 
To test our research hypotheses, we construct a sample of large UK firms. These are the constituents of the FTSE350 index between 1999 and 2015. The final sample consists of 489 unique firms, 1,078 unique CEOs and 4,727 firm years. We obtain data from three main data sources: BoardEx, Datastream, and Thomson's SDC Platinum. In terms of our variables of interest, we focus on three different types to capture the CEO foreign experience: foreign nationality, international education and foreign working experience.

This study produces new and significant findings in the areas of corporate finance and international business. First, it documents that foreign CEOs earn significantly higher total compensation than domestic CEOs. The magnitude of this effect is large and significant. Estimates suggest an average foreign CEO pay premium of about 16 per cent $(t=5.024$, $p=0.000)$ after controlling for other firm-level and corporate governance factors. The findings also show that national CEOs with foreign work experience earn significantly higher total compensation than other domestic CEOs. Again, the magnitude of the effect is both large and significant. The estimates suggest an average pay premium of about 10 per cent $(t=4.620$, $p=0.000$ ) after controlling for other economic and governance factors. However, there is no evidence that national CEOs with foreign education (as distinct from foreign work experience) earn significantly different pay from other CEOs. The broad findings of this study are consistent with the presumption that foreign CEOs possess detailed knowledge of the region from which they originate (i.e. human capital) and that national CEOs with foreign working experience possess useful networks of local contacts, personal networks with managers in foreign firms and internal advice networks (i.e. social capital). Neither of these can easily be obtained through foreign education alone.

Second, the study documents partial evidence that the relationship between CEOs' foreign experience and total compensation differs when a firm's level of internationalization varies, as measured by its percentage of foreign sales. This provides important information 
about the mechanism for foreign CEOs' pay premiums. Previous studies suggest that firms with higher degrees of international exposure may find the CEOs' foreign knowledge and networks particularly valuable (Daily, Certo and Dalton, 2000; Roth, 1995). Although our results for CEO foreign working experience is consistent with this line of argument, our results for CEO foreign nationality suggest that it is important for firms in different degree of internationalization.

Third, we find that CEOs' foreign experience has a positive impact on firms' levels of internationalization, and that firms are more likely to expand into regions where the CEOs obtained their foreign experience. In addition, CEOs with foreign working experience moderate the negative impact of cultural differences between acquirer and target countries during foreign acquisitions. The results suggest that foreign pay premiums are partly attributable to CEOs' specialist foreign expertise, rather than broader general managerial skills.

The main empirical results are robust to alternative estimation methods. The initial results are isolated using panel data methods, controlling for firm and corporate governance characteristics. However, recognizing that the selection of international CEOs may be endogenous, propensity score-matching methods are used to ensure that firms hiring international CEOs are statistically similar to firms hiring domestic CEOs. The propensity score-matching algorithm provides a contemporary approach to address such endogeneity challenges. The results reveal that the average treatment effect of foreign experience is approximately 10 per cent and is statistically significant, with a t-statistic of 2.79 . In addition, the main results are robust to the use of lead-lag regressions, the negative binominal regressions and the quadratic regressions. Overall, empirical analysis of the UK data unambiguously points to pay premiums for CEOs' foreign-experience. 
Therefore, this study makes several important empirical contributions to a growing literature on the impact and relevance of CEO characteristics. First, while prior international business literature focuses on the value of CEOs' foreign experience from the firms' perspective, our research advances scholarly knowledge by showing the significant value of foreign experience from the CEOs' perspective. The study sheds light on the economic value of foreign experience to a CEO, as measured by a CEO's compensation premium. Second, the study contributes to the debate on whether generalized or specialized CEO skills are more valuable to a CEO. While previous studies indicate that general skills are more important, the results of this study suggest that the pay premium depends on CEOs' foreign experience that generates specific foreign expertise and networks. Third, this study is believed to be the first to provide detailed analysis of different channels through which foreign experience can be obtained: education, working experience or nationality.

The remainder of this paper is organized as follows. Section 2 provides an overview of relevant theories and presents the hypotheses; Section 3 describes the sample, methodology and variables; Section 4 presents the empirical results; and Section 5 summarizes and concludes.

\section{Literature and hypothesis development}

\subsection{Foreign experience and CEO compensation}

Research on top managers has increased dramatically since Bertrand and Schoar's (2003) influential econometric study showed that top managers have a statistically significant effect on corporate behavior. However, the business and management literature has long recognized the importance of top managers in value creation. In a pioneering study, Dearborn and Simon (1958) concluded that managers with different functional backgrounds vary in 
their attitudes, knowledge and perspectives, leading to different strategic decisions. Building on Dearborn and Simon (1958)'s study, Hambrick and Mason (1984) developed upper echelons theory (UE), which states that organizational outcomes can to an extent be predicted by the top management team's background characteristics. Decision-making in organizations is complicated by uncertainty, ambiguity and competing goals. Top managers will use their cognitive bases and values to filter the information, interpret the situation and make strategic decisions. UE theory relies on previous research and posits that demographic characteristics (age, education, functional background, personality and other experience) serve to filter and interpret that information.

Although not specified in Mason and Hambrick (1984), international experience is expected to influence managers' abilities and perceptions in making decisions in a similar way. Prior research has confirmed the advantages to the firm of managers with international experience. Using US Fortune 500 firms, Carpenter, Sanders, and Gregersen (2001) and Daily, Certo, and Dalton (2000) show that firms with international CEOs have better financial performance. In terms of strategic decisions, Herrmann and Datta (2005) show that managers with international experience perceive lower risks associated with foreign expansion than managers from different backgrounds with different levels of experience, and are therefore more likely to engage in foreign direct investments. These results are confirmed by Nielsen and Nielsen (2011) and Piaskowska and Trojanowski (2014).

While it is well-established that foreign experience has benefits to the firm, it is unclear what the benefits to the CEO are. This study combines UE with resource dependence theory (RDT). RDT asserts that organizations are comprised of bundles of unique resources that are the key to organizational success. These resources and how a firm relies on them will ultimately affect firms' behavior and strategy (Salancik and Pfeffer, 1978). CEOs' foreign experience is valuable as it is both non-substitutable and inimitable (Carpenter, Sanders, and 
Gregersen, 2001; Daily, Certo, and Dalton, 2000): it is non-substitutable as it provides CEOs with skills that are not easily substituted through other channels (Sambharya, 1996; Sullivan, 1994) and is inimitable as it is a function of unique historical conditions (Barney, 1991). These factors create competitive advantage for firms in the right organizational context and increase CEOs' market value. Moreover, in an era of globalization, as firms start to target fast-growing foreign markets and aim to develop market share abroad, more firms are in need of top managers with foreign experience (Lublin, 1996). Compared with the demand, the supply of CEO candidates with foreign experience is lacking. RDT therefore suggests that firms should offer higher rewards in order to recruit and retain talented CEOs (Coff, 1997) as their foreign experience are valuable for firm performance as indicated by UE.

On the one hand, the previous literature suggests that valuable network capital increases executives' bargaining power in the labor market, and that this is reflected in executive compensation (Brown et al., 2012; Engelberg, Gao, and Parsons, 2013; Geletkanycz, Boyd, and Finkelstein, 2001). In terms of human capital, international experience develops global mindsets in top managers, enabling them to engage in global operations (Piaskowska and Trojanowski, 2014; Sambharya, 1996). In particular, foreign CEOs have detailed knowledge of the region from which they originate, including economic and market factors as well as institutions such as culture and norms (Nielsen and Nielsen, 2010).

On the other hand, critics of the above view point out that knowledge of the firm and the industry, together with general expertise in a specific area, may be more important than foreign experience. They argue that firms with 'domestic' CEOs with no foreign experience may also be successful, as international complexity can be managed through region managers, expatriates, locals or consultants (Carpenter, Sanders, and Gregersen, 2000). Moreover, prior literature has found little empirical support for human capital factors explaining variation in 
executive compensation (Leonard, 1990). In order to answer the empirical question of whether CEOs with foreign experience receive higher pay, the following hypothesis is posited:

H1. There is a positive association between total CEO compensation and CEO foreign experience.

\subsection{The moderating effect of firm internationalization}

In the context of international strategic decisions, top managers with international experience are vital in connecting firms to international markets, as they possess valuable social and human capital. In terms of social capital, international experience enables managers to build useful networks of local contacts (Blomstermo et al., 2004), personal networks with managers in foreign firms (Useem, 1984), and internal advice networks (Athanassiou and Nigh, 2005).

In addition to CEO foreign experience, the firm's level of internationalization may also affect CEO total compensation levels for several reasons. First, the CEO's ability to manage international complexity may be better realized and more critical to firms with increasing international commitments (Ghoshal and Bartlett, 1990; Sanders and Carpenter, 1998). Moreover, as the level of firm internationalization increases, information-processing demands and the task complexity of a CEO increases (Carpenter and Sanders, 2004; Conyon

et al., 2013). From an upper echelons perspective CEOs' international experience may be more important for firms with higher levels of international exposure as interpretation and filtering of information to make decisions will be more challenging. Consequently, if foreign experience is more important and can contribute more in such instances, CEOs with such skills should receive a compensation premium over CEOs without such experience. 
Second, the value of the CEO's foreign experience increases as firms strengthen their global strategic positioning and increase CEO's discretion and bargaining power (Carpenter and Fredrickson, 2001). Greater managerial discretion may lead to higher levels of CEO pay (Finkelstein and Boyd, 1998). This line of reasoning suggests that the degree of firm internationalization acts an important moderating factor in the relation between CEO compensation and CEO foreign experience. Accordingly, we hypothesize that:

H2. The higher the level of firm internationalisation, the stronger (i.e. more positive) the effect of CEOs' foreign experience on total CEO compensation.

\subsection{Foreign experience and firms' international expansion}

The rationale for Hypotheses 1 and 2 is the expectation that CEOs' foreign experience is valuable to the firm. From an upper echelons perspective, firms with CEOs who have foreign experience are more likely to engage in foreign markets. Foreign experience among top managers has been associated with lower psychological distance in doing business overseas, in the form of appreciating differences in language, culture, business practices and legislation (Melin, 1992), greater awareness of international opportunities (Black, 1997), better ability to deal with the uncertainty associated with international opportunities (Carpenter, Pollock, and Leary, 2003; Sambharya, 1996), and greater confidence in foreign environments (Tung and Miller, 1990).

From a resource dependence perspective, CEOs with foreign experience provide unique and vital resources to connect firms with international markets. Foreign experience develops CEOs' international networks, which in turn provide critical resources enabling firms to compete in the global environment (Daily, Certo, and Dalton, 2000; Roth, 1995). CEOs with foreign experience also have better knowledge of foreign local markets as well as relevant stakeholders (e.g. suppliers, customers, employers), leading to better identification of 
attractive investments. Furthermore, hiring an international CEO signals a firm's willingness to explore foreign markets, increasing its credibility among investors and stakeholders (Schmid and Dauth, 2014).

All of the above factors are likely to result in CEOs with foreign experience expanding their firms into foreign markets (Erramilli, 1991) and performing better in acquisitions. Accordingly, it is hypothesized that:

H3a. CEOs' foreign experience is positively associated with firms' foreign expansion.

H3b. CEOs' foreign experience is positively associated with firms' foreign acquisition performance.

\section{Sample and Methodology}

\subsection{Data sources and sample}

We use data from four separate sources. CEO compensation data, corporate governance variables and CEO characteristics are obtained from BoardEx; missing CEO nationality is manually filled based on FAME; firm-level data, including firm revenues, stock returns and accounting data are derived from Datastream; data on foreign acquisitions are obtained from Thomson's SDC Platinum; and cultural distance index data are obtained from Hofstede's cultural dimensions. 
The sample for this study consists of all firms in the UK's FTSE 350 index between 1999 and $2015 .^{2}$ We include only firms that are located in the UK. After excluding firms with missing financial, stock market, corporate governance and CEO demographic background information, the final sample consists of 489 unique firms, 1,070 unique CEOs and 4,727 firm years. The final sample contains 193 unique foreign CEOs and 793 firm years with foreign CEOs, representing approximately 17 per cent of the original sample.

\subsection{Methodology}

First, to test our hypotheses, the following panel data regression model is estimated:

$$
y_{i t}=\alpha+\beta * \text { ForeignExperience }_{i t}+\sum \gamma * \text { ControlVariables }_{i t}+\sum \text { Industry }_{k}+\sum \text { Year }_{t}+\varepsilon_{i t}
$$

The dependent variable $y_{i t}$ is CEO total compensation for Hypotheses 1 and 2, and level of internationalization and acquisition performance for Hypothesis 3 . ForeignExperience $_{i t}$ captures three different types of foreign experience: nationality, education and working experience. ControlVariablesit contains a set of firm-level control variables. Definitions of the main variables are presented in Appendix A and explained in Section 3.3. In addition, a set of industry dummies is included to capture inter-industry differences, and a set of year dummies is included to control for macro-economic shocks.

It is difficult to identify statistically the causal effect of foreign experience on CEO compensation. An ideal experimental design would require the random assignment of firms into treatment and control groups, which is rare in general and impossible in this context

\footnotetext{
${ }^{2}$ The constituent list of FTSE 350 firms is downloaded from Datastream for the beginning of each year (January).
} 
(Oxelheim et al., 2013). The OLS estimation proposed here assumes that the presence of an international CEO is exogenous. However, it is likely to be endogenous, and depends on both the firm's demand for this attribute and the willingness of the candidate to join the firm (Estélyi and Nisar, 2016; Masulis, Wang, and Xie, 2012). More specifically, executives with foreign experience may be attracted to multinational firms because of their international skill sets. Alternatively, firms seeking to expand internationally may hire these international CEOs.

The endogeneity of CEO selection is documented in the previous literature. Magnusson and Boggs (2006) show that CEO selection decisions are influenced by both CEOs' international experience and firms' levels of internationalization. Focusing on foreign executive appointments, Greve, Biemann, and Ruigrok (2015) find that such appointments are associated with individual experiential characteristics, the prior performance of the firm and the firm's overall level of internationalization. Therefore, a general concern in the literature is that firms that employ international CEOs may be different from firms that do not, for predictable and observable reasons. If these are correlated with the presence of international CEOs, estimates derived from the OLS estimator will be biased and inconsistent. In other words, in comparing two different firms, the coefficient of foreign experience estimated by OLS will be overstated, as it captures the effect of other covariates in addition to whether the CEO has foreign experience.

This study employs a propensity score-matching design to deal with the endogeneity concern. This is a valid way to mitigate endogeneity if matching between CEOs and firms may be based on predictable/observable characteristics (Angrist and Pischke, 2008; 
Armstrong, Ittner, and Larcker, 2012; Rosenbaum and Rubin, 1983). ${ }^{3}$ The purpose of propensity score matching is to find a set of firms employing domestic CEOs that is as statistically alike as possible to a set of firms employing international CEOs, using a matching algorithm with observable features (Heckman, Ichimura, and Todd, 1998; Imbens, 2000). This then enables the average treatment effect of the treated international CEO group (i.e. ATT) to be determined. In other words, after matching, differences in total compensation could be attributed to whether or not the CEO have foreign experience, rather than to differences in the other covariates.

\subsection{Dependent variables}

To test Hypotheses 1 and 2 we require a measure of CEO total compensation. This is sum of salary, bonus, the value of stock options granted during the fiscal year, and the value of restricted stock or other equity granted during the fiscal year. The data are measured at annual intervals using data drawn from BoardEx. Table 1 shows that the average CEO in the sample earned approximately $£ 1,818,000$. The median value is significantly lower, at around $£ 1,090,000$, indicating that the distribution of CEO total compensation is skewed. Therefore, the natural logarithm is used in the empirical analyses.

\footnotetext{
${ }^{3}$ In principle, the panel nature of the data would have allowed the inclusion of firm-level fixed effects, but we chose not to do so. Instead, the analysis relied on OLS and propensity score matching. Because the focus is on the $\mathrm{CEO}$ rather than the firm, the main variables of interest have low within-firm variation. Also, the other righthand-side variables in the regression model are time-invariant. As a result, including firm-level fixed effects would have absorbed much of the variation under investigation. Therefore, a firm-level fixed effects estimator is not used. An alternative technique to deal with potentially endogenous right-hand-side variables is to use instrumental variables. However, it is unclear $e x$ ante what the correct identification restriction is that would determine the selection of international CEOs but not total compensation. Therefore, appropriate instruments are hard to find. The strategy adopted in this study is to address the potential endogenous selection of foreign CEOs using propensity score matching methods.
} 
To test Hypotheses $3 \mathrm{a}$ and $3 \mathrm{~b}$, we capture foreign expansion by the level of internationalization with two measures: the percentage of foreign sales and the likelihood of foreign acquisitions. ${ }^{4}$ We capture firm's foreign performance by acquisition performance with short-term cumulative abnormal returns around the acquisition announcement date. ${ }^{5} \mathrm{We}$ employ two event windows $(-1,+1)$ and $(-5,+1)$. The three-day window $(-1,+1)$ has been commonly used in merger and acquisition literature and we also include a longer event window $(-5,+1)$ to take into account the possibility of information leakage before the official deal announcement (Aybar and Ficici, 2009; Schmid and Dauth, 2014).

\{Insert Table 1 about here $\}$

\subsection{Independent variables}

Our central explanatory variables are CEO foreign experience. Previous studies use different measures to capture top managers' international experience; and the insights from such studies inform out analyses. Early research relied on the number of years of international assignments (Carpenter and Fredrickson, 2001; Daily, Certo, and Dalton, 2000; Sullivan, 1994). As top managers' internationalization is a multi-dimensional phenomenon, a more comprehensive measure is required to fully capture top managers' international exposure (Lee and Park, 2006). Black (1997) uses nationality of the top management team as

\footnotetext{
${ }^{4}$ As sales data in Datastream contain limitations, we follow Dastidar (2009) approach to obtain our final data with adjustments tailored for our study (see detail in Appendix C).

${ }^{5}$ Calculation details are available upon request.
} 
a proxy for international orientation. Herrmann and Datta (2005) calculate the percentage of individuals in the top management team with international work experience. In addition, with a concern that any indicator only covers a certain aspect of managers' international experience (Nielsen, 2010), some studies produce a composite index by combining several types of international experience (Lee and Park, 2008; Oxelheim et al., 2013; Schmid and Dauth, 2014). However, the effects of each type are then overlooked.

This study seeks to fill this void by analyzing three distinct types of CEO foreign experience: foreign nationality, international education and foreign working experience. These are captured by Foreign CEO, National CEO with foreign education and National CEO with foreign working experience. Since foreign CEOs are likely to have foreign education and foreign working experience, only national CEOs' foreign education and working experience are considered in order to isolate their impact from that of foreign CEOs. By not combining several types into a single index, as in the previous literature, this study provides detailed analysis of the impact of each type. Appendix B presents the country distribution of foreign CEOs' nationality in this study. The largest number of non-UK CEOs is from the US, followed by Ireland, Australia and France. As shown in Table 1, around 17 per cent of CEOs in the sample are of foreign nationality, 13 per cent have foreign education, and 38 per cent have foreign working experience.

\subsection{Control variables}

In addition to the main explanatory right-hand side variables, a set of firm-specific economic and corporate governance control variables are also used. Previous studies find that these variables have a potentially important effect on CEO compensation (Carpenter, Sanders, and Gregersen, 2001; Murphy, 1999). 
With regards to firm-specific economic controls, the size of the firm is proxied by the logarithm of sales. The positive correlation between CEO compensation and firm size is one of the most robust findings in the CEO pay literature (Murphy, 1999). We also control for the firms' level of internationalization, which is proxied by the firm's percentage of foreign sales. To avoid confounding the impact of international diversification and industrial diversification, the number of industry segments is also included (Carpenter, Sanders, and Gregersen, 2001; Dastidar, 2009; Giannetti, Liao, and Yu, 2015). All three of these control variables account for the degree of organizational complexity, arising from firm scale and globalization. Agency theory, too, predicts that CEO compensation is determined by firm performance, signaling CEO effort (Murphy, 1999; Holmstrom, 1979). Firm performance is proxied by returns on assets and stock returns, capturing accounting-based and market-based performance. Firm growth opportunity is proxied by the market-to-book ratio. Firm risk is proxied by stock volatility and leverage. Stock volatility is the standard deviation of annualized monthly stock re-turns over the calendar year, and leverage is computed as total debt over total assets. The measurement of these is consistent with prior studies (Core, Holthausen and Larcker, 1999).

In terms of corporate governance controls, board characteristics are captured by the natural logarithm of board size, the natural logarithm of compensation committee size, CEOchair duality and non-executive ratio. CEOs' skills and experience are proxied by the logarithms of CEO age and tenure. In addition, the study controlled for the effect of internationalization of the board (Carpenter, Geletkanycz, and Sanders, 2004; Certo et al., 2006; Finkelstein et al., 2009). Boards' nationality diversity is proxied by the Blau index of diversity (Blau, 1977). As shown in Table 1, firm-level characteristics and corporate governance variables are consistent with other studies based on UK data (Conyon, Peck, and Sadler, 2009; Gerakos, Piotroski, and Srinivasan, 2013). 
In examining acquisition performance, following the previous literature (Aybar and Ficici, 2009), our study also controls for common acquisition deal-specific characteristics. These include relative size, prior cross-border acquisition experience, publicly-listed target, acquirer and target firms being in the same industry, cash/stock payments only, tender offers and stakes held prior to acquisition. In addition, a cultural distance index (CDI) ${ }^{6}$ is included to measure cultural differences between target and acquiring countries, as well as interactions between difference types of CEO foreign experience and CDI. Higher value of cultural distance means higher cultural distance between target and acquiring countries.

\section{Empirical Results}

Before conducting the multivariate regression analysis, we first compute Pearson correlation coefficients between the independent variables to ensure the validity of the regression results. Table 2 shows the resulting correlation matrix, which indicates no severe multicollinearity problems. We also compute the variance inflation factors (VIFs) of independent variables for each regression and show the highest VIF at the bottom of regression tables. All values are below a recommended threshold value of ten (Hair et al., 2009), confirming multicollinearity is not a major problem in our analyses.

\{Insert Table 2 about here

\footnotetext{
${ }^{6}$ The cultural distance index is computed based on methods used in Aybar and Ficici (2009), and we extend their method by including all six dimensions (they used four) as the data covers large number of countries since 2011.
} 


\subsection{Foreign experience and CEO compensation}

Table 3 shows the results of the analyses testing Hypotheses 1 and 2 based on the OLS estimator (with robust standard errors). ${ }^{7}$ Column 1 includes the variables of interest (Hypothesis 1). Except for national CEO with foreign education, the coefficients for both foreign $\mathrm{CEO}$ and national $\mathrm{CEO}$ with foreign working experience are positively correlated with total compensation. The economic magnitudes of these two CEO foreign experience coefficients are also significant. CEOs with foreign nationality and national CEOs with foreign working experience received higher total compensation, by approximately 35 per cent $(t=9.205, p=0.000)$ and 17 per cent $(t=6.159, p=0.000)$ respectively. This may be explained by variations in the quantity and quality of value provided by different types of foreign experience.

Foreign CEOs provide valuable human capital to the firm as they have detailed knowledge of the region from which they originate, including economic and market factors as well as institutions such as culture and norms. On the other hand, national CEOs with foreign working experience provide firms with valuable social capital, as they have useful networks of local contacts, personal networks with managers in foreign firms and internal advice networks. Neither of these can be easily obtained through foreign education.

Column 2 of Table 3 includes common controls predicting total compensation. While the coefficients for foreign $\mathrm{CEO}$ and national CEO with foreign working experience remain

\footnotetext{
${ }^{7}$ Year and industry dummies are included but are not reported for ease of exposition. We also experimented with including other CEO characteristics such as gender and the log of CEO network size. The main results are robust to including these factors. Results available on request.
} 
significant, their economic magnitudes decrease to 16 per cent $(t=5.024, p=0.000)$ and 10 per cent $(t=4.620, p=0.000)$ respectively. The impact of foreign experience is still substantial, increasing total pay by around a third. These results are consistent with Hypothesis 1 . The coefficients for the control variables are consistent with previous studies based on UK data (Conyon, Peck, and Sadler, 2009; Kabir and Minhat, 2014). We recognize that firms might need to provide higher compensation to attract willing candidates to move from home and work in a foreign country. However, unlike foreign CEOs, national CEOs who have foreign working experience or education probably live domestically and do not require the extra incentive to move abroad when being appointed. Our results show that not only foreign CEOs, but also CEOs with foreign working experience receive higher compensation, indicating that the result found is not due to labor mobility.

Column 3 includes interactions between the three types of CEO foreign experience and the percentage of foreign sales, enabling analysis of the moderating effect of levels of internationalization on the relationship between CEO foreign experience and total compensation (Hypothesis 2). In terms of foreign CEOs, while the coefficient remains significant $(\beta=0.148, t=2.298, p=0.022)$, its interaction with the percentage of foreign sales is insignificant $(t=0.500, p=0.617)$. On the other hand, while the coefficient for national CEOs with foreign working experience becomes insignificant $(t=1.398, p=0.162)$, the coefficient for the interaction with the percentage of foreign sales is positive and significant $(\beta=0.140$, $t=2.372, p=0.018)$. In general, we find partial evidence towards Hypothesis 2 that firms with higher levels of internationalization might be willing to pay more to recruit and retain CEOs with foreign experience. It is possible that firms hire CEOs from a specific region because they have intention to expand into that region. However, we believe firms hire an international CEO, not only for their knowledge of a specific region, but also for the global mind-set that a CEO develops through prior foreign experience, which might provide long 
term benefits to the firm (Gupta and Govindarajan 2002; Levy et al., 2007; Sambharya, 1996; Piaskowska and Trojanowski, 2012). In particular, Foreign experience among top managers has been associated with lower psychological distance in doing business overseas, in the form of appreciating differences in language, culture, business practices and legislation (Melin, 1992), greater awareness of international opportunities (Black, 1997), better ability to deal with the uncertainty associated with international opportunities (Carpenter et al., 2003; Sambharya, 1996), and greater confidence in foreign environments (Tung and Miller, 1990).

\{Insert Table 3 about here $\}$

To better understand the effects of foreign experience on CEO compensation, two further analyses are performed. First, each of the foreign experience variables is examined in greater depth in Table 4. The highest VIF presented in each column indicates that there is not a serious multi-collinearity problem among each sub-set of foreign experiences variables. In Column 1, Foreign CEOs are split between foreign CEOs without UK experience, foreign CEOs with UK education and foreign CEOs with UK working experience. Results reveal that foreign CEOs without any UK experience and foreign CEOs with UK working experience are responsible for the main impact of foreign CEOs. A foreign CEO with UK working experience also has a statistically significant impact on total compensation, indicating that UK working experience is also valuable for a foreign CEO. In Column 2, national CEOs with foreign education are then split between those with foreign MBA education and foreign nonMBA education. Neither of these are significant, which is inconsistent with our expectation that foreign MBA provides a vital channel for CEOs to gain social capital (e.g. international networks), which will be rewarded in compensation contracts. In Column 3, national CEOs 
with foreign working experience are split between those with foreign board experience and foreign non-board experience. Both foreign board and non-board experience contribute to the impact of national CEOs with foreign working experience, suggesting that firms appreciate not only the skills and reputation of CEOs who have foreign board working experience, but also the networks that CEOs gain from foreign non-board experience. The results also suggest that firms value both CEOs' human capital, and their social capital stemming from foreign experience.

\{Insert Table 4 about here $\}$

Second, the potential 'US CEO' effect is considered in Table 5. Gerakos, Piotroski, and Srinivasan (2013) find that greater market interaction with the US market by non-US firms is associated with greater use of US-style pay as a reduction in the US-UK pay gap. To examine whether US-related CEOs drive the main effect of foreign CEOs, we split all three types of foreign experience into US experience and non-US foreign experience. Similar as Table 4, Column 1 shows the results of the split of foreign nationality. The results reveal that the coefficients of both US CEOs and non-US foreign CEOs are statistically and economically significant, indicating that foreign CEO effect matters in addition to the US CEO effect. In Column 2, we split the foreign education and find marginal positive effect in CEO with US education while no effect in CEO with non-US foreign education. In Column 3, we split the foreign working experience. Similar to foreign nationality, we find that national CEO with non-US foreign working experience has significant effect on CEO total compensation in addition to the US foreign working experience. In general, the results 
suggest that the foreign experience effect does not reflect US effect solely and that non-US foreign experience have incremental effect on the US experience.

In summary, the empirical results largely confirm Hypothesis 1 and 2. The findings reveal that the presence of both foreign CEOs and national CEOs with foreign working experience is positively correlated with total compensation. However, we only find partial evidence that levels of firm internationalization have a moderating effect on this relation.

\{Insert Table 5 about here $\}$

\subsection{Endogeneity}

A primary concern is that the presence of an international CEO may be endogenous. As described earlier, this study primarily employs a propensity score-matched pair research design to help resolve selection bias. The propensity score matching method proceeds in two steps. The first step is to predict the selection decision of international CEOs, by estimating a probit model of the binary outcome that equals one if the firm hires an international CEO, with observable firm characteristics as explanatory variables. ${ }^{8}$ Table 6 shows the results of two probit models (one with economic covariates only, and the other with economic and governance covariates). All explanatory variables are lagged by one year, while controlling for industry and year.

\footnotetext{
${ }^{8}$ We find that firm characteristics have different effects on firms' choice of CEOs with different types of foreign experience. To investigate a set of universal factors, a composite international experience indicator is employed that equals one if the CEO has any type of foreign experience.
} 
The results in Table 6 show that firms that hired an international CEO differ systematically from those that did not, indicating that the selection of international CEOs is strongly endogenous with firm-level characteristics. The results shown in Column 1, which includes only economic covariates, suggest that more internationalized firms are more likely to hire international CEOs, consistent with Magnusson and Boggs' (2006) and Miletkov, Poulsen, and Wintoki's (2016). Also, the results indicate that larger and more industrially diversified firms that perform less well and have higher risk are more likely to select international CEOs. The results in Column 2, which includes both economic and governance covariates, show that governance covariates also influence the choice of international CEOs. Board diversity, board size, the independent director ratio are positively correlated with the presence of international CEOs, while the coefficients for the size of compensation committee and CEO tenure are negative.

\{Insert Table 6 about here $\}$

Consistent with the previous literature (Greve, Biemann, and Ruigrok, 2015; Magnusson and Boggs, 2006), the findings of this study suggest that appointments of international CEOs are influenced by firm size, the quality of corporate governance, firms' levels of internationalization, prior performance, and the experiential characteristics of CEO candidates. The predicted probability (i.e. the propensity score) of the presence of 
international CEOs, shown in Column 2 of Table 6, forms the basis of the matching procedure.

In the second step, we match firms using a nearest neighbor algorithm with caliper 0.01 , with no replacement and we restrict the observations to be on the common support. ${ }^{9}$ Table 7 presents the average treatment effect of international experience on the total compensation. ${ }^{10}$ After matching based on firm economic and governance characteristics, we find that the difference of the mean log compensation between the treated group and control group decreases from 0.26 to 0.10 which is around one third of reduction, indicating that the impact of CEO foreign experience is overstated before the matching (i.e. with OLS). Even so, the economic impact is still significant. Moreover, we find that the difference after the matching is statistically significant with t-statistics at 2.79 , indicating that compensation premium on CEO foreign experience still exists after controlling for selection effects. ${ }^{11}$

In addition to the propensity score matching, following Ozkan (2011) and Hartzell and Starks (2003), we use lagged explanatory variables (i.e. lead-lag regression) to alleviate the concern of endogeneity with regards to reverse causality. Results in Table 8 Panel A suggest that our main results are not sensitive to the lead-lag regression models.

\footnotetext{
${ }^{9}$ Appendix D provides assessment of the efficacy of our matching by examining the covariate balance between the matched pairs.

${ }^{10}$ We find that 2,793 out of 3,898 observations are in common support, indicating sufficient observations for us to make valid inferences. We achieve much more observations $(3,880)$ in common support if we require replacement. However, as the observations are not independent when matched with replacement, we prefer not to use replacement (Peel and Makepeace, 2012). The results are not sensitive with or without replacement.

${ }^{11}$ It is worth noting that while OLS regressions provides an average estimate of pay premium for the whole sample (ATE), matched treatment premiums (ATT) are restricted and can only be generalized to the common support (Peel and Makepeace, 2012; Tucker, 2010).
} 
In summary, compensation premiums for CEO foreign experience remain statistically and economically significant after applying propensity score matching and lead-lag regression approach.

\{Insert Table 7 about here $\}$

\subsection{Alternative modelling approaches}

Two alternative approaches are considered to confirm the robustness of our results. First, while we take the natural logarithm of CEO total compensation to address the skewed distribution issue and apply it in our OLS regressions, previous studies suggest negative binominal and Poisson models as alternative approaches (Cameron and Trivedi, 1998). ${ }^{12}$ The advantage of negative binominal and Poisson models compare to OLS is that they will not provide negative predicted values for CEO total compensation (Manner, 2010). As both negative binomial and the Poisson models are designed for dependent variables that are nonnegative discrete integers, we convert total compensation into count data. The resulting count variable of total compensation has a median of 2 , mean of 3.04 and variance of 17.46 . As the variance is greater than the mean (i.e. over-dispersion), a negative binominal regression is more appropriate rather than Poisson regression. The results are shown in Table 8 Panel B. The findings show that our main results are robust to the negative binominal models.

\footnotetext{
${ }^{12}$ We thank the referee for suggesting this approach.
} 
Second, based on methods explained in Haans et al. (2016), the length of foreign working experience and its square ${ }^{13}$ are used for examining potential quadratic relationship between CEO foreign experience and total compensation. We expect an inverted U-shaped pattern, that CEOs with moderate level of foreign experience might receive higher compensation than other CEOs with too much or too little foreign experience. The mean and median years of CEO foreign working experience is 15.04 and 13 , respectively. In Table 8 Panel C, we include both the length of foreign working experience and its square term. Both Column 1 and Column 2 show no evidence of a quadratic relation as the coefficient for the square term is insignificant. In other words, it is unlikely that a CEO will find a negative impact on compensation for having too much foreign experience.

\{Insert Table 8 about here $\}$

\subsection{Foreign experience and firms' international expansion}

Table 9 shows the results of analyses testing Hypotheses $3 \mathrm{a}$ and $3 \mathrm{~b}$. The first analysis tests whether CEO foreign experience affected firms' levels of internationalization (Panel A). ${ }^{14}$ Similar patterns of results are found with two different measures (the percentage of foreign sales and the likelihood of foreign acquisitions). In general, the coefficients for both

\footnotetext{
${ }^{13}$ Length of foreign working experience captures the number of years a CEO has spent in working for foreign companies not located in the UK.

${ }^{14}$ Consistent with the M\&A literature, to investigate acquisitions, a reduced sample (acquisition sample) is used, consisting of 2,176 100-per-cent stake acquisitions completed by UK firms from 1999 to 2015. Following Moeller and Schlingemann (2005), acquisitions are only considered where the bidder ended up owning 100 per cent of the target firm's assets or an entire subsidiary and the transaction value exceeds one million dollars.
} 
foreign CEOs and national CEOs with foreign working experience are positively associated with higher levels of internationalization. This shows that CEOs with foreign experience are associated with the firm's capacity to expand globally. ${ }^{15}$ The geographic connection between CEO foreign experience and firms' expansion strategy is considered in Column 3 and 6, by including the interactions between different types of foreign experience and an indicator (i.e. Same region) that equals one if the CEO has foreign experience in the same region of the foreign sales or acquisitions. The coefficients for all three interactions are positive and significant, indicating that firms' internationalization and the foreign experience of CEOs are geographically connected. These results are consistent with Hypothesis $3 \mathrm{a}$ and provide strong evidence that CEOs' foreign experience in a specific region increases firms' investment opportunities in that region.

An event study (Table 9 Panel B) is conducted to investigate whether CEOs' foreign experience affected firms' acquisition performance, but this provides no evidence of correlation between CEOs' foreign experience and short-term performance. ${ }^{16}$ However, a negative coefficient for the CDI indicates that the higher the cultural distance between target and acquirer country, the lower the short-term performance. The coefficient for the interaction between national CEOs with foreign working experience and CDI is positive and significant (Column 3: $\beta=0.004, t=2.057, p=0.039$; Column 6: $\beta=0.005, t=1.855, p=0.064$ ).

\footnotetext{
${ }^{15}$ Since some firms have no foreign sales, the model is also examined using Tobit regressions left-censored at zero, with similar results. In addition, to account for the possibility of reverse causality, the actual percentage of foreign sales is replaced with changes in the percentage of foreign sales, and the results still hold.

${ }^{16}$ In further robustness tests, a variety of different event windows are also used, including windows dates from $(-3,+3),(-5,+5),(10,+10)$, and $(-10,+5)$. We find that the main qualitative results highlighted in the text remain intact.
} 
This suggests that CEOs with foreign working experience buffer the negative impact of CDI on short-term acquisition performance, ameliorating the 'liability of foreignness'.

We also conducted an analysis to examine whether the CEO's foreign experience affects the firm's overall performance, captured by returns on assets and stock returns (results not tabulated). ${ }^{17} \mathrm{We}$ were unable to isolate a consistent statistical relation between these measures of firm performance and CEO foreign experience. This suggests that CEOs with foreign experience are not necessarily 'better' or 'more valuable' than their counterparts with less foreign experience. We interpret this as meaning that the CEO pay premium observed for CEOs with foreign experience is not simply because they possess better general managerial skills that are valuable to the firm.

In summary, the results suggest that CEOs with specialist foreign knowledge may be the best match for firms where such knowledge is an important component of the CEO skills set. The results also suggest that the pay premium for CEOs with foreign experience is attributable to the value of their foreign expertise rather than their general managerial skills.

\{Insert Table 9 about here $\}$

\section{Conclusions}

This study investigates the relationship between measures of a CEO's foreign experience and their total compensation. The process of globalization is increasing the

\footnotetext{
${ }^{17}$ Regression results are available upon request.
} 
demand for scarce internationally-seasoned CEOs, and such forces are likely to increase the price of CEO talent. This idea is tested using data from a sample of large UK firms between 1999 and 2015.

Our research provides compelling empirical evidence that CEO pay is higher with the more foreign experience has amassed compared to domestic-only experience. This is the main empirical finding of our study. An array of diagnostic tests are performed to ensure the general robustness of the main findings. Specifically, the observed foreign CEO pay premium is robust to controlling for firm-specific and corporate governance characteristics, as well as the endogenous determination of international CEO status. The results also suggest that pay premiums for international CEOs are attributable to the value of their foreign expertise and foreign networks, stemming from foreign experience, rather than their general managerial skills.

This study has significant and potentially far ranging implications for other scholars, as well as for practicing managers. Given the substantial private returns of foreign experience to CEOs, as well as to their firms, this study highlights the potential importance of investing in foreign experience as a crucial part of the accumulation of human and social capital. In addition, firms might find it beneficial to invest in their executives' international experience as a mechanism to generate important future competitive advantage, and executives might be encouraged to undertake such opportunities for career development. Our empirical results suggest a positive-sum game, whereby both firms and CEOs gain form international experience. Moreover, in showing that CEOs' foreign experience influences their corporate strategy decisions, this study highlights the importance of fit and complementarity between executive experience and the firm. The CEO selection process might be optimized to better match with corporate strategy, thereby gaining competitive advantage, especially in the global market. Last, but not least, by documenting that CEO foreign experience affects 
acquisition performance, this study provides practical trading strategies for investors, especially around announcements of foreign acquisitions.

As with all studies, our research has a range of limitations that might form the basis for future research. A single study cannot hope to address fully all issues in a research domain, but our research has suggested some important future avenues for investigation. First, our study is based on a set of large UK firms. Although these are major enterprises, accounting for an overwhelming share of capitalization on UK equity markets, it raises the question of whether the results are generalizable to other types of UK firms not include in the sample (e.g. small firms and/or private firms). Also, although we believe our results are reasonably generalizable to other highly developed capital markets that share similar features as UK, we encourage future studies to confirm our results in other context and are generalizable to the rest of the world. Second, due to data limitations, it is not possible to examine alternative proxies of firms' foreign activities, such as foreign production, geographic dispersion and cross-listings. These are, of course, other important features of the firm's corporate decision making. Whilst we have examined highly salient features of strategic decision making (returns to owners, corporate acquisitions) the list of all strategic decisions was not exhausted. Future studies might also explore other aspects in which international CEOs might help create value for firms, such as access to international capital, and the choice of capital structure in terms of the amount of equity or leveraged debt in the firm.

In addition, this paper provides some contribution to upper echelons theory (UE) by documenting empirical evidence on the following two aspects. First, Hambrick (2007) provides an updated view of UE and argues future research could incorporate research on compensation and UE theory and study the interaction. Second, Hambrick (2007) 
acknowledges that UE theory has mainly been tested on US firms and it is unknown if the theory holds in other environments.

In conclusion, this study provides a better understanding of how CEOs' foreign experience determines their compensation contracts, and should act as a spur to further research in the field of CEO compensation and international management. 


\section{Acknowledgements}

We would like to thank Igor Filatotchev, Greg Bell, Annette Poulsen, Sujata Banerjee, Sinziana Dorobantu, Sohnke Bartram, Denis Schweizer, David Mauer, Gaberiel Beneito, Ugur Lel, Steve Thompson, Shantanu Banerjee, Lerong He, Wayne Landsman, Beatriz Garcia Osma, and participants at the Journal of Corporate Finance Paper Development Conference. In addition, we thank participants at the EAA $32^{\text {nd }}$ Doctoral Colloquium and the ESRC-NWDTC workshops 2015 (at The University of Manchester) and 2014 (at Lancaster University) for helpful comments. Research assistance was provided by Daisy Zhu. 


\section{References}

1. Allen \& Overy (2015). M\&A Index, Q3 2015. London: Allen \& Overy.

2. Angrist, J. D., \& Pischke, J.-S. (2008). Mostly Harmless Econometrics: An Empiricist's Companion. Princeton, NJ: Princeton University Press.

3. Antia, M., Lin, J. B., \& Pantzalis, C. (2007). Cultural distance and valuation of multinational corporations. Journal of Multinational Financial Management, 17(5), 365-383.

4. Armstrong, C. S., Ittner, C. D., \& Larcker, D. F. (2012). Corporate governance, compensation consultants, and CEO pay levels. Review of Accounting Studies, 17(2), 322-351.

5. Athanassiou, N., \& Nigh, D. (2005). The impact of US company internationalization on top management team advice networks: A tacit knowledge perspective. In I. Nonaka (ed.), Knowledge Management: Critical Perspectives on Business and Management, Vol. 3. Oxford: Taylor \& Francis, pp. 79-94.

6. Aybar, B., \& Ficici, A. (2009). Cross-border acquisitions and firm value: An analysis of emerging-market multinationals. Journal of International Business Studies, 40(8), $1317-1338$.

7. Barney, J. (1991). Firm resources and sustained competitive advantage. Journal of Management, 17(1), 99-120.

8. Beber, A., \& Fabbri, D. (2012). Who times the foreign exchange market? Corporate speculation and CEO characteristics. Journal of Corporate Finance, 18(5), 1065-1087.

9. Berger, P. G., \& Ofek, E. (1995). Diversification's effect on firm value. Journal of Financial Economics, 37(1), 39-65.

10. Bertrand, M., \& Schoar, A. (2003). Managing with style: The effect of managers on firm policies. The Quarterly Journal of Economics, 118(4), 1169-1208.

11. Black, S. S. (1997). Top management team characteristics: A study of their impact on the magnitude on international operations and international performance. Doctoral dissertation, Columbia University, New York, NY.

12. Blau, P. M. (1977). A Macrosociological Theory of Social Structure1.American Journal of Sociology, 83(1), 26-54.

13. Blomstermo, A., Eriksson, K., Lindstrand, A., \& Sharma, D. D. (2004). The perceived usefulness of network experiential knowledge in the internationalizing firm. Journal of International Management, 10(3), 355-373.

14. Brookhart, M. A., Schneeweiss, S., Rothman, K. J., Glynn, R. J., Avorn, J., \& Stürmer, T. (2006). Variable selection for propensity score models. American Journal of Epidemiology, 163(12), 1149-1156.

15. Brockman, P., Lee, H. S. G., \& Salas, J. M. (2016). Determinants of CEO compensation: Generalist-specialist versus insider-outsider attributes. Journal of Corporate Finance, 39, 53-77. 
16. Brown, R., Gao, N., Lee, E., \& Stathopoulos, K. (2012). What are friends for? CEO networks, pay and corporate governance. In S. Boubaker, B. D. Nguyen, \& D. K. Nguyen (eds), Corporate Governance. Berlin, Germany: Springer, pp. 287-307.

17. Bryan, S., Nash, R., \& Patel, A. (2015). The effect of cultural distance on contracting decisions: The case of executive compensation. Journal of Corporate Finance, 33, 180-195.

18. Butler, A. W., \& Gurun, U. G. (2012). Educational networks, mutual fund voting patterns, and CEO compensation. The Review of Financial Studies, 25(8), 2533-2562.

19. Burns, N., Jindra, J., \& Minnick, K. (2017). Sales of Private Firms and the Role of CEO Compensation. Journal of Corporate Finance, 43, 444-463.

20. Caliendo, M. (2006). Microeconometric Evaluation of Labour Market Policies. Berlin, Germany: Springer Science \& Business Media.

21. Caliendo, M., \& Kopeinig, S. (2008). Some practical guidance for the implementation of propensity score matching. Journal of Economic Surveys, 22(1), 31-72.

22. Cameron, C. A., \& Trivedi, P. K. (1998). Regression Analysis of Count Data. Cambridge: Cambridge University Press.

23. Carpenter, M. A., \& Fredrickson, J. W. (2001). Top management teams, global strategic posture, and the moderating role of uncertainty. Academy of Management journal, 44(3), 533-545.

24. Carpenter, M. A., Geletkanycz, M. A., \& Sanders, W. G. (2004). Upper echelons research revisited: Antecedents, elements, and consequences of top management team composition. Journal of Management, 30(6), 749-778.

25. Carpenter, M. A., Pollock, T. G., \& Leary, M. M. (2003). Testing a model of reasoned risk-taking: Governance, the experience of principals and agents, and global strategy in high-technology IPO firms. Strategic Management Journal, 24(9), 803-820

26. Carpenter, M. A., Sanders, W., \& Gregersen, H. B. (2000). International assignment experience at the top can make a bottom-line difference. Human Resource Management, 39(2-3), 277-285.

27. Carpenter, M. A., Sanders, W. G., \& Gregersen, H. B. (2001). Bundling human capital with organizational context: The impact of international assignment experience on multinational firm performance and CEO pay. Academy of Management Journal, 44(3), 493-511.

28. Certo, S. T., Lester, R. H., Dalton, C. M., \& Dalton, D. R. (2006). Top management teams, strategy and financial performance: A meta-analytic examination. Journal of Management Studies, 43(4), 813-839.

29. Coff, R. W. (1997). Human assets and management dilemmas: Coping with hazards on the road to resource-based theory. Academy of Management Review, 22(2), 374402.

30. Conyon, M. J., Peck, S. I., \& Sadler, G. V. (2009). Compensation consultants and executive pay: Evidence from the United States and the United Kingdom. The Academy of Management Perspectives, 23(1), 43-55. 
31. Conyon, M. J., Peck, S. I., \& Sadler, G. V. (2011). New perspectives on the governance of executive compensation: an examination of the role and effect of compensation consultants. Journal of Management \& Governance, 15(1), 29-58.

32. Conyon, M. J., Fernandes, N., Ferreira, M. A., Matos, P., \& Murphy, K. J. (2013). The executive compensation controversy: A transatlantic analysis. In T. Boeri, C. Lucifora, \& K. J. Murphy (eds), Productivity, Profit and Pay. Oxford: Oxford University Press, pp. 9-115.

33. Core, J.E., Holthausen, R.W. and Larcker, D.F., 1999. Corporate governance, chief executive officer compensation, and firm performance. Journal of Financial Economics, 51(3), 371-406.

34. Cumming, D., Filatotchev, I., Knill, A., Reeb, D. M., \& Senbet, L. (2017). Law, finance, and the international mobility of corporate governance. Journal of International Business Studies, 1-25.

35. Daily, C. M., Certo, S. T., \& Dalton, D. R. (2000). International experience in the executive suite: the path to prosperity?. Strategic Management Journal, 21(4), 515523.

36. Dastidar, P. (2009). International corporate diversification and performance: Does firm self-selection matter. Journal of International Business Studies, 40(1), 71-85.

37. Dearborn, D. C., \& Simon, H. A. (1958). Selective perception: A note on the departmental identifications of executives. Sociometry, 21(2), 140-144.

38. El-Khatib, R., Fogel, K., \& Jandik, T. (2015). CEO network centrality and merger performance. Journal of Financial Economics, 116(2), 349-382.

39. Engelberg, J., Gao, P., \& Parsons, C. A. (2013). The price of a CEO's rolodex. Review of Financial Studies, 26(1), 79-114.

40. Erramilli, M. K. (1991). The experience factor in foreign market entry behavior of service firms. Journal of International Business Studies, 22(3), 479-501.

41. Estélyi, K. S., \& Nisar, T. M. (2016). Diverse boards: Why do firms get foreign nationals on their boards?. Journal of Corporate Finance, 39, 174-192.

42. Fernandes, N., Ferreira, M. A., Matos, P., \& Murphy, K. J. (2013). Are US CEOs paid more? New international evidence. Review of Financial Studies, 26(2), 323-367.

43. Ferri, F., \& Maber, D. A. (2013). Say on pay votes and CEO compensation: Evidence from the UK. Review of Finance, 17(2), 527-563.

44. Finkelstein, S., \& Boyd, B. K. (1998). How much does the CEO matter? The role of managerial discretion in the setting of CEO compensation. Academy of Management journal, 41(2), 179-199.

45. Finkelstein, S., Hambrick, D. C., \& Cannella, A. A. (2009). Strategic Leadership: Theory and Research on Executives, Top Management Teams, and Boards. Oxford: Oxford University Press.

46. Geletkanycz, M. A., Boyd, B. K., \& Finkelstein, S. (2001). The strategic value of CEO external directorate networks: Implications for CEO compensation. Strategic Management Journal, 22(9), 889-898. 
47. Gerakos, J. J., Piotroski, J. D., \& Srinivasan, S. (2013). Which US market interactions affect CEO pay? Evidence from UK companies. Management Science, 59(11), 24132434.

48. Ghoshal, S., \& Bartlett, C. A. (1990). The multinational corporation as an interorganizational network. Academy of Management Review, 15(4), 603-626.

49. Giannetti, M., Liao, G., \& Yu, X. (2015). The brain gain of corporate boards: evidence from China. The Journal of Finance, 70(4), 1629-1682.

50. Gupta, A. K., \& Govindarajan, V. (2002). Cultivating a global mindset. The Academy of Management Executive, 16(1), 116-126.

51. Greve, P., Biemann, T., \& Ruigrok, W. (2015). Foreign executive appointments: A multilevel examination. Journal of World Business, 50(4), 674-686.

52. Haans, R. F., Pieters, C., \& He, Z. L. (2016). Thinking about U: Theorizing and testing U-and inverted U-shaped relationships in strategy research. Strategic Management Journal, 37(7), 1177-1195.

53. Hair, J. F., Black, W. C., Babin, B. J., \& Anderson, R. E. (2009). Multivariate Data Analysis 7th edn. Upper Saddle River, NJ: Pearson Prentice Hall.

54. Hambrick, D. C., \& Mason, P. A. (1984). Upper echelons: The organization as a reflection of its top managers. Academy of Management Review, 9(2), 193-206.

55. Hambrick, D. C. (2007). Upper echelons theory: An update. Academy of Management Review, 32(2), 334-343.

56. Hartzell, J. C., \& Starks, L. T. (2003). Institutional investors and executive compensation. The Journal of Finance, 58(6), 2351-2374.

57. Heckman, J. J., Ichimura, H., \& Todd, P. (1998). Matching as an econometric evaluation estimator. The Review of Economic Studies, 65(2), 261-294.

58. Herrmann, P., \& Datta, D. K. (2002). CEO successor characteristics and the choice of foreign market entry mode: An empirical study. Journal of International Business Studies, 33(3), 551-569.

59. Herrmann, P., \& Datta, D. K. (2005). Relationships between top management team characteristics and international diversification: an empirical investigation*. British Journal of Management, 16(1), 69-78.

60. Hölmstrom, B. (1979). Moral hazard and observability. The Bell Journal of Economics, 74-91.

61. Imbens, G. W. (2000). The role of the propensity score in estimating dose-response functions. Biometrika, 87(3), 706-710.

62. Kabir, R., \& Minhat, M. (2014). Compensation consultants and CEO pay. Research in International Business and Finance, 32, 172-189.

63. Lee, H. U., \& Park, J. H. (2006). Top team diversity, internationalization and the mediating effect of international alliances*. British Journal of Management, 17(3), 195-213.

64. Lee, H. U., \& Park, J. H. (2008). The influence of top management team international exposure on international alliance formation. Journal of Management Studies, 45(5), 961-981. 
65. Leonard, J. S. (1990). Executive Pay and Firm Performance. Industrial and Labor Relations Review, 43, 13S-29S.

66. Levy, O., Beechler, S., Taylor, S., \& Boyacigiller, N. A. (2007). What we talk about when we talk about 'global mindset': Managerial cognition in multinational corporations. Journal of International Business Studies, 38(2), 231-258.

67. Lins, K., \& Servaes, H. (1999). International evidence on the value of corporate diversification. The Journal of Finance, 54(6), 2215-2239.

68. Lockett, A., \& Thompson, S. (2001). The resource-based view and economics. Journal of Management, 27(6), 723-754.

69. Lublin, J. (1996). An overseas stint can be a ticket to the top. Wall Street Journal, 29 January.

70. Magnusson, P., \& Boggs, D. J. (2006). International experience and CEO selection: An empirical study. Journal of International Management, 12(1), 107-125.

71. Manner, M. H. (2010). The impact of CEO characteristics on corporate social performance. Journal of Business Ethics, 93, 53-72.

72. Masulis, R. W., Wang, C., \& Xie, F. (2012). Globalizing the boardroom-The effects of foreign directors on corporate governance and firm performance. Journal of Accounting and Economics, 53(3), 527-554.

73. Melin, L. (1992). Internationalization as a strategy process. Strategic Management Journal, 13(S2), 99-118.

74. Miletkov, M., Poulsen, A., \& Wintoki, M. B. (2016). Foreign independent directors and the quality of legal institutions. Journal of International Business Studies, 1-26.

75. Moeller, S. B., \& Schlingemann, F. P. (2005). Global diversification and bidder gains: A comparison between cross-border and domestic acquisitions. Journal of Banking \& Finance, 29(3), 533-564.

76. Murphy, K. J. (1999). Executive compensation. Handbook of Labor Economics, 3, 2485-2563.

77. Nielsen, A. P. S. (2010). Top management team internationalization and firm performance. Management International Review, 50(2), 185-206.

78. Nielsen, S., \& Nielsen, B. B. (2010). Why do firms employ foreigners on their top management team? An exploration of strategic fit, human capital and attractionselection-attrition perspectives. International Journal of Cross Cultural Management, 10(2), 195-209.

79. Nielsen, B. B., \& Nielsen, S. (2011). The role of top management team international orientation in international strategic decision-making: The choice of foreign entry mode. Journal of World Business, 46(2), 185-193.

80. Nielsen, B. B., \& Nielsen, S. (2013). Top management team nationality diversity and firm performance: A multilevel study. Strategic Management Journal, 34(3), 373-382.

81. Norburn, D. (1989). The chief executive: A breed apart. Strategic Management Journal, 10(1), 1-15.

82. Osawa, J., \& Wong, G. (2015). International experience strengthens new alibaba chief's hand. Wall Street Journal, 10 May. 
83. Oxelheim, L., Gregorič, A., Randøy, T., \& Thomsen, S. (2013). On the internationalization of corporate boards: The case of Nordic firms. Journal of International Business Studies, 44(3), 173-194.

84. Ozkan, N. (2011). CEO compensation and firm performance: An empirical investigation of UK panel data. European Financial Management, 17(2), 260-285.

85. Peel, M. J., \& Makepeace, G. H. (2012). Differential audit quality, propensity score matching and Rosenbaum Bounds for confounding variables. Journal of Business Finance \& Accounting, 39(5-6), 606-648.

86. Pfeffer, J., \& Salancik, G. R. (1978). The External Control of Organizations: A Resource Dependence Perspective. New York, NY: Harper and Row.

87. Piaskowska, D., \& Trojanowski, G. (2014). Twice as smart? The importance of managers' formative-years' international experience for their international orientation and foreign acquisition decisions. British Journal of Management, 25(1), 40-57.

88. Rajgopal, S., Taylor, D., \& Venkatachalam, M. (2012). Frictions in the CEO labor market: The role of talent agents in CEO compensation. Contemporary Accounting Research, 29(1), 119-151.

89. Rosenbaum, P. R., \& Rubin, D. B. (1983). The central role of the propensity score in observational studies for causal effects. Biometrika, 70(1), 41-55.

90. Roth, K. (1995). Managing international interdependence: CEO characteristics in a resource-based framework. Academy of Management Journal, 38(1), 200-231.

91. Sambharya, R. B. (1996). Foreign experience of top management teams and international diversification strategies of US multinational corporations. Strategic Management Journal, 17(9), 739-746.

92. Sanders, W. G., \& Carpenter, M. A. (1998). Internationalization and firm governance: The roles of CEO compensation, top team composition, and board structure. Academy of Management Journal, 41(2), 158-178.

93. Schmid, S., \& Dauth, T. (2014). Does internationalization make a difference? Stock market reaction to announcements of international top executive appointments. Journal of World Business, 49(1), 63-77.

94. Stahl, G. K., \& Tung, R. L. (2015). Towards a more balanced treatment of culture in international business studies: The need for positive cross-cultural scholarship. Journal of International Business Studies, 46(4), 391-414.

95. Sullivan, D. (1994). Measuring the degree of internationalization of a firm. Journal of International Business Studies, 25(2), 325-342.

96. Tucker, J. W. (2010). Selection bias and econometric remedies in accounting and finance research. Journal of Accounting Literature, 29, 31-57.

97. Tung, R. L., \& Miller, E. L. (1990). Managing in the twenty-first century: The need for global orientation. MIR: Management International Review, 30(1), 5-18.

98. Useem, M. (1984). The Inner Circle: Large Corporations and the Rise of Business Political Activity in the US and UK. New York, NY: Oxford University Press.

99. Vander Bauwhede, H., \& Willekens, M. (2008). Disclosure on corporate governance in the European Union. Corporate Governance: An International Review, 16(2), 101115. 


\section{Appendix A. Variable definitions}

This appendix defines the variables used in the study. Accounting and stock return data are form DataStream, corporate governance and compensation data are from BoardEx, foreign acquisition data are from Thomson's SDC, and cultural distance data are from Hofstede's cultural dimensions.

\begin{tabular}{ll}
\hline Variable & Definition \\
\hline CEO characteristics &
\end{tabular}

Foreign CEO (non-UK)

National CEO with foreign education

National CEO with foreign working experience

CEO with any type of foreign experience

Log of CEO age

Log of CEO tenure

\section{CEO compensation}

\author{
Log Salary \\ Log Total Comp \\ Salary fraction \\ Bonus fraction
}

Equity fraction

Log CEO wealth
An indicator variable equals to one if the CEO has non-UK nationality; zero otherwise (Constructed from Boardex: Nationality Mix)

An indicator variable equals to one if the $\mathrm{CEO}$ is British but has foreign education at the bachelor level or higher; zero otherwise (Constructed from Boardex: Education (Country))

An indicator variable equals to one if the $\mathrm{CEO}$ is British but has foreign working experience, including board and non-board role, current and historic; zero otherwise (Constructed from Boardex: Employment (Country))

An indicator variable equals to one if the CEO has any type of foreign experience: nationality, foreign education and/or foreign working experience; zero otherwise

The log of CEO age (Boardex: Age (Years))

The log of the number of years the CEO has held the role at the firm (Boardex: Time in Role in Years)

The log of base annual pay (Boardex: Salary)

The log of the sum of all compensation: Salary, Bonus, Equity-linked, Pension, Other (Boardex: Total Compensation)

Salary as a proportion of total compensation (Boardex: Salary/Total

Compensation)

Bonus as a proportion of total compensation (Boardex: Bonus/Total Compensation)

Equity-linked pay as a proportion of total compensation (Boardex: Equity Linked/Total Compensation)

The log of the value of cumulative holdings over time of stock, Options and LTIPs for the CEO (Boardex: Total Wealth) 


\begin{tabular}{|c|c|}
\hline Variable & Definition \\
\hline \multicolumn{2}{|l|}{ Firm foreign activities } \\
\hline Percentage of foreign sales & $\begin{array}{l}\text { The percentage of foreign sales over total sales (DataSteam: relevant } \\
\text { Geographic segment 1-10 Sales (WC19601 91)/ Net Sales or Revenue } \\
\text { (WC01001)) }\end{array}$ \\
\hline Foreign Acquisition & $\begin{array}{l}\text { An indicator variable equals to one if the firm has foreign acquisition } \\
\text { (Thomson's SDC: Target Nation) }\end{array}$ \\
\hline $\operatorname{CAR}(-1,+1)$ & $\begin{array}{l}\text { The }(-1,+1) 3 \text {-day window acquirer cumulative abnormal return on } \\
\text { announcement using the market adjusted model (Constructed from } \\
\text { DataStream: Price Index }(\mathrm{PI}))\end{array}$ \\
\hline $\operatorname{CAR}(-5,+1)$ & $\begin{array}{l}\text { The }(-5,+1) 7 \text {-day window acquirer cumulative abnormal return on } \\
\text { announcement using the market adjusted model (Constructed from } \\
\text { DataStream: Price Index }(\mathrm{PI}) \text { ) }\end{array}$ \\
\hline \multicolumn{2}{|l|}{ Firm characteristics } \\
\hline Log sales & The log of sales (DataStream: Net Sales Or Revenue (WC01001)) \\
\hline Stock returns (1 year) & [(RIt/RIt-1)-1]*100\% (DataStream: Total Return Index (RI)) \\
\hline Return on Asset & $\begin{array}{l}\text { Net income divided by total assets (DataStream: Net Income Before } \\
\text { Preferred Dividends (WC01651)/Total Assets (WC02999)) }\end{array}$ \\
\hline Stock volatility & $\begin{array}{l}\text { A measure of a stock's average annual price movement to a high and low } \\
\text { from a mean price for each year (DataStream: Price Volatility (WC08806)) }\end{array}$ \\
\hline Leverage & $\begin{array}{l}\text { Total debt divided by total assets (DataStream: Total Debt \% Total Capital } \\
\text { (WC08221) }\end{array}$ \\
\hline Market to book value & $\begin{array}{l}\text { The market value of the ordinary equity divided by the balance sheet value } \\
\text { of the ordinary equity in the company (DataStream: Market To Book Value } \\
\text { (MTBV)) }\end{array}$ \\
\hline Number of product sections & $\begin{array}{l}\text { The total number of different product segments. (Constructed from } \\
\text { Datastream: WC19501 91) }\end{array}$ \\
\hline
\end{tabular}




\begin{tabular}{ll}
\hline Variable & Definition \\
\hline Governance characteristics &
\end{tabular}

Log of board size

Foreign Directors \%

Blau index

Non-executive ratio

CEO is Chairman

Log comp. comm. size

\section{Acquisition deal characteristics}

Relative Size

Cultural Distance Index

Prior cross-border acquisition experience

Target (Publicly listed)

Same Industry

Cash payment only

Stock payment only

Tender Offer

Stake held prior to acquisition
The log of total number of directors on the board (Boardex: Total Directors on the Board)

The number of foreign directors over the total number of directors on the board (Constructed from Boardex: Nationality Mix \& Total Directors on the Board)

The Blau index for nationality heterogeneity is measured as $1-\sum_{i=1}^{n} P_{i}^{2}$, where $\mathrm{P}$ is the percentage of board members in each category and $\mathrm{n}$ is the total number of category. Values of the Blau index range from 0 to 0.5 , with maximum occurs when the board comprises an equal number of British and Foreign directors.

The number of non-executive directors over the total number of directors on the board (Boardex Number of Independent NED on Board/Total Directors on the Board)

An indicator variable equals to one if the CEO is also the chairman (Boardex: Combined role of CEO \& Chairman is present)

The log of total number of remuneration committee numbers (Boardex: Remuneration/Compensation Committee Size)

The ratio calculated as transaction value divided by acquirer market capitalization at the announcement day (Thomson's SDC: Value of Transaction (\$mil) \& DataStream: FTSMVUSD)

Takes values between 1 and 0 , with values close to 1 and 0 implies significant cultural distance and proximity, respectively (Constructed from Hofstede's cultural dimensions)

An indicator variable equals to one if the acquirer firm has prior crossboarder acquisition experience (Constructed from Thomson's SDC from 1985 to current acquisition date)

An indicator variable equals to one if the target firm is publicly listed (Thomson's SDC: Target Public Status)

An indicator variable equals to one if the acquirer and target share the same 2-digit SIC code (Thomson's SDC: Acquirer \& Target Primary SIC Code)

An indicator variable equals to one if the deal is for cash payment only (Thomson's SDC: \% of Cash)

An indicator variable equals to one if the deal is for stock payment only (Thomson's SDC: \% of Stock)

An indicator variable equals to one if the deal is a tender offer (Thomson's SDC: Tender Offer)

The percentage of acquiring firm's initial stake in target firm prior to the acquisition announcement (Thomson's SDC: Percent of Shares Held at Announcement) 


\section{Appendix B. CEO nationality distribution}

\section{B.1. By country}

\begin{tabular}{|c|c|c|c|}
\hline Nationality Mix & Freq. & Percent & Cum \\
\hline Argentine & 3 & 0.06 & 0.06 \\
\hline Australian & 65 & 1.38 & 1.44 \\
\hline Belgian & 8 & 0.17 & 1.61 \\
\hline Canadian & 28 & 0.59 & 2.2 \\
\hline Chilean & 13 & 0.28 & 2.48 \\
\hline Dutch & 30 & 0.63 & 3.11 \\
\hline French & 80 & 1.69 & 4.8 \\
\hline German & 22 & 0.47 & 5.27 \\
\hline Greek & 9 & 0.19 & 5.46 \\
\hline Indian & 8 & 0.17 & 5.63 \\
\hline Indonesian & 1 & 0.02 & 5.65 \\
\hline Irish & 90 & 1.9 & 7.55 \\
\hline Israeli & 1 & 0.02 & 7.57 \\
\hline Italian & 17 & 0.36 & 7.93 \\
\hline Jordanian & 7 & 0.15 & 8.08 \\
\hline Kazakhstani & 7 & 0.15 & 8.23 \\
\hline New Zealander & 16 & 0.34 & 8.57 \\
\hline Norwegian & 4 & 0.08 & 8.65 \\
\hline Pakistani & 6 & 0.13 & 8.78 \\
\hline Peruvian & 5 & 0.11 & 8.89 \\
\hline Portuguese & 2 & 0.04 & 8.93 \\
\hline Russian & 6 & 0.13 & 9.05 \\
\hline Singaporean & 6 & 0.13 & 9.18 \\
\hline South African & 49 & 1.04 & 10.22 \\
\hline Swedish & 48 & 1.02 & 11.23 \\
\hline Swiss & 7 & 0.15 & 11.38 \\
\hline U.K. & 3,934 & 83.22 & 94.61 \\
\hline U.S. & 252 & 5.33 & 99.94 \\
\hline Zimbabwean & 3 & 0.06 & 100 \\
\hline Total & 4,727 & 100 & \\
\hline
\end{tabular}

\section{B.2. By region}

\begin{tabular}{lccc}
\hline Region & Freq. & Percent & Cum. \\
\hline Africa & 49 & 6.18 & 6.18 \\
Asia & 15 & 1.89 & 8.07 \\
Europe & 323 & 40.73 & 48.8 \\
North America & 280 & 35.31 & 84.11 \\
Oceania & 81 & 10.21 & 94.33 \\
South America & 18 & 2.27 & 96.6 \\
Rest of the World & 27 & 3.4 & 100 \\
\hline Total \# Foreign CEOs & 793 & 100 & \\
\hline
\end{tabular}




\section{Appendix C. The percentage of foreign sales}

We use sales data in Datastream to measure the percentage of foreign sales. As the sales data in Datastream contain limitations which require special attention, we follow Dastidar (2009) approach to obtain our final data with adjustments tailored for our study. Sales data for each firm year in Datastream are broken down by product segment and geographic segments. The first limitation is that the maximum segment number is ten, so if a company has more than ten segments the remaining segments are included in segment 10. Nevertheless, this happens very rate in our study. The second limitation is that since there is no clear definition of the scope of each segment, the data provided by the firm are inconsistent. Some firms provide sales segment data by country while others are by region. As a result, we divided the sample into broader regions rather than countries. ${ }^{18}$ In our study, we focus on both developed and emerging markets according to Standard \& Poor list, and divided these countries into six regions: Asia, Europe, North America, Africa, South America, and Oceania. We consider all other countries as Rest of the world. A breakdown of the countries is provided below. The third limitation is that the segment sales represent international operations that include export sales when they cannot be isolated out. However, according to Datastream, this only represents a small fraction of the total data. Furthermore, accounting data on Datastream are primarily consolidated data while the segment data are not. As a result, the sum of the segment sales could be greater than the firm's total sales. In such case, we drop these observations. Dastidar (2009) point out that the results do not change materially if these observations are included. In addition, we drop observations where the segment of sales is less than 90\% of total sales (Berger and Ofek, 1995; Lins and Servaes, 1999)

Breakdown of geographic segments by regions ${ }^{19}$

\begin{tabular}{ll}
\hline Region & Countries \\
\hline Asia & Bangladesh, China, Hong Kong, \\
Europe & Austria, Belgium, Czech Repub \\
& Netherlands, Norway, Poland, Por \\
North America & Canada, Mexico, US \\
Africa & Egypt, Morocco, South Africa \\
South America & Brazil, Chile, Columbia, Peru \\
Oceania & Australia, New Zealand \\
Rest of the world & All other countries
\end{tabular}

Rest of the world

All other countries

${ }^{18}$ Domestic operations data is in geographic segment 1 fields. In our study, we use U.K. sales as domestic sales, however, it is noted that some firms report Europe and U.K. sales as domestic sales. This might introduce potential measurement error when calculate percentage of foreign sales. In robustness test, we include an indicator variable that equals one if the domestic sales are consisted of U.K. and Europe to control for such effect, our main results remain consistent.

${ }^{19}$ All countries listed below are either emerging markets or developed markets according to S\&P list, while all other countries are considered as rest of the world. 


\section{Appendix D. Covariate balance}

These tables assess the efficacy of matching by examining covariate balance between matched pairs. First, we compare the sample means of each covariate between the treated group and control groups using parametric $t$ tests. In general, Table D.1. shows that before the matching, the means of almost all covariates between these two groups are significantly different, except for the market to book ratio and log of CEO age. There is no statistically significant difference in the means of all the covariates after the matching, indicating that matching procedures effectively increase the similarity between treatment and control groups. Second, we assess standardized bias before and after matching, together with the reduction in bias. We find that for most covariates, bias reduction exceeds $80 \%$, except for Market to book ratio. All of our covariates are below the desirable threshold of $10 \%$ after matching. Also, Table D.2. shows that the mean (median) bias of the set of covariates reduces from $8.9 \%(6.6 \%)$ to $1.8 \%(1.5 \%)$. In sum, the results provide confidence that compensation premium can be estimated for firms with similar observed characteristics.

D.1. Individual covariate balance

\begin{tabular}{|c|c|c|c|c|c|c|}
\hline \multicolumn{3}{|c|}{ Mean } & \multirow[b]{2}{*}{ \%bias } & \multicolumn{2}{|c|}{ \% reduct } & \multirow{2}{*}{$\begin{array}{l}\text { t-test } \\
\text { p-value }\end{array}$} \\
\hline Variable & Treated & Control & & |bias & t-stat & \\
\hline \multicolumn{7}{|c|}{ Percentage of foreign sales $(\mathrm{t}-1)$} \\
\hline Unmatched & 0.47 & 0.33 & 40.9 & & 12.51 & 0.00 \\
\hline Matched & 0.39 & 0.38 & 1.2 & 97.2 & 0.28 & 0.78 \\
\hline \multicolumn{7}{|c|}{ Number of product segment $(\mathrm{t}-1)$} \\
\hline Unmatched & 3.00 & 2.56 & 25.3 & & 7.69 & 0.00 \\
\hline Matched & 2.75 & 2.73 & 0.6 & 97.6 & 0.15 & 0.88 \\
\hline \multicolumn{7}{|l|}{ Log of sales $(\mathrm{t}-1)$} \\
\hline Unmatched & 13.55 & 13.18 & 22.3 & & 6.71 & 0.00 \\
\hline Matched & 13.27 & 13.31 & -1.9 & 91.2 & -0.49 & 0.62 \\
\hline \multicolumn{7}{|l|}{ ROA (t-1) } \\
\hline Unmatched & 0.04 & 0.06 & -20 & & -6.09 & 0.00 \\
\hline Matched & 0.05 & 0.05 & 1.7 & 91.3 & 0.45 & 0.65 \\
\hline \multicolumn{7}{|l|}{ Price volatility $(\mathrm{t}-1)$} \\
\hline Unmatched & 0.31 & 0.29 & 19.4 & & 5.87 & 0.00 \\
\hline Matched & 0.30 & 0.30 & 0.1 & 99.7 & 0.02 & 0.99 \\
\hline \multicolumn{7}{|l|}{ Market to book ratio (t-1) } \\
\hline Unmatched & 2.86 & 2.96 & -2 & & -0.62 & 0.53 \\
\hline Matched & 2.85 & 3.06 & -4 & -99.4 & -0.96 & 0.34 \\
\hline \multicolumn{7}{|c|}{ Blau Index of Board Diversity (Nationality) (t-1) } \\
\hline Unmatched & 0.25 & 0.14 & 60.4 & & 18.33 & 0.00 \\
\hline Matched & 0.18 & 0.18 & -1.1 & 98.2 & -0.27 & 0.79 \\
\hline \multicolumn{7}{|l|}{ Log of board size (t-1) } \\
\hline Unmatched & 2.17 & 2.10 & 27.4 & & 8.33 & 0.00 \\
\hline Matched & 2.12 & 2.12 & -1 & 96.2 & -0.26 & 0.79 \\
\hline \multicolumn{7}{|l|}{ Non-executive ratio (t-1) } \\
\hline Unmatched & 0.52 & 0.49 & 18.5 & & 5.67 & 0.00 \\
\hline Matched & 0.50 & 0.50 & -2 & 89.2 & -0.51 & 0.61 \\
\hline \multicolumn{7}{|c|}{ Log of comp. comm. size $(\mathrm{t}-1)$} \\
\hline Unmatched & 1.31 & 1.29 & 8.3 & & 2.56 & 0.01 \\
\hline Matched & 1.30 & 1.30 & -0.4 & 95.7 & -0.09 & 0.93 \\
\hline \multicolumn{7}{|l|}{ Log of CEO age (t-1) } \\
\hline Unmatched & 3.94 & 3.94 & 3 & & 0.93 & 0.35 \\
\hline Matched & 3.94 & 3.93 & 0.6 & 80.7 & 0.14 & 0.89 \\
\hline \multicolumn{7}{|l|}{ Log of CEO tenure $(t-1)$} \\
\hline Unmatched & 1.17 & 1.36 & -17.7 & & -5.43 & 0.00 \\
\hline Matched & 1.28 & 1.26 & 2.4 & 86.4 & 0.6 & 0.55 \\
\hline
\end{tabular}

D.2. Covariate set balance

\begin{tabular}{lcc}
\hline Sample & Mean Bias & Median Bias \\
\hline Unmatched & 8.9 & 6.6 \\
Matched & 1.8 & 1.5 \\
\hline
\end{tabular}




\section{Table 1}

Descriptive statistics. This table shows summary statistics for the key variables for a sample of all FTSE 350 firms from 1999 to 2015. CEO compensation-related variables are reported in 000s of GBP.

\begin{tabular}{|c|c|c|c|c|}
\hline Variable & Number & Mean & Std Dev & Median \\
\hline \multicolumn{5}{|l|}{ CEO characteristics } \\
\hline Foreign CEO (non-UK) & 4727 & 0.168 & 0.374 & 0.000 \\
\hline National CEO with foreign education & 4727 & 0.132 & 0.339 & 0.000 \\
\hline National CEO with foreign working experience & 4727 & 0.384 & 0.486 & 0.000 \\
\hline CEO age & 4727 & 51.846 & 6.399 & 52.000 \\
\hline CEO tenure & 4727 & 5.628 & 5.520 & 3.900 \\
\hline \multicolumn{5}{|l|}{ CEO compensation } \\
\hline Total compensation $(£ 000)$ & 4727 & 1818 & 2755 & 1090 \\
\hline \multicolumn{5}{|l|}{ Firm foreign activities } \\
\hline Percentage of foreign sales & 4727 & 0.424 & 0.357 & 0.413 \\
\hline Foreign Acquisition & 2176 & 0.505 & 0.500 & 1.000 \\
\hline $\operatorname{CAR}(-1,+1)$ & 2176 & 0.007 & 0.046 & 0.004 \\
\hline $\operatorname{CAR}(-5,+1)$ & 2176 & 0.005 & 0.060 & 0.004 \\
\hline \multicolumn{5}{|l|}{ Firm characteristics } \\
\hline Net Sales/Revenues & 4727 & 3322205 & 11800000 & 666100 \\
\hline Stock returns (1 year) & 4727 & 0.196 & 0.653 & 0.132 \\
\hline Return on Asset & 4727 & 0.045 & 0.153 & 0.051 \\
\hline Stock volatility & 4727 & 0.301 & 0.106 & 0.278 \\
\hline Leverage & 4727 & 0.317 & 3.586 & 0.343 \\
\hline Market to book ratio & 4727 & 2.582 & 39.046 & 2.030 \\
\hline \multicolumn{5}{|l|}{ Governance characteristics } \\
\hline Board size & 4727 & 8.914 & 2.565 & 9.000 \\
\hline Non-executive ratio & 4727 & 0.515 & 0.145 & 0.500 \\
\hline CEO is Chairman & 4727 & 0.196 & 0.397 & 0.000 \\
\hline Compensation committee size & 4727 & 3.845 & 1.112 & 4.000 \\
\hline Blau Index of Board Diversity (Nationality) & 4727 & 0.180 & 0.200 & 0.125 \\
\hline
\end{tabular}




\section{Table 2}

Correlations. This table shows Pearson correlation coefficients between the independent variables.

\begin{tabular}{|c|c|c|c|c|c|c|c|c|c|c|c|c|c|c|c|c|c|}
\hline & & 1 & 2 & 3 & 4 & 5 & 6 & 7 & 8 & 9 & 10 & 11 & 12 & 13 & 14 & 15 & 16 \\
\hline 1 & Foreign CEO & 1 & & & & & & & & & & & & & & & \\
\hline 2 & National CEO with foreign education & -0.18 & 1 & & & & & & & & & & & & & & \\
\hline 3 & National CEO with foreign working experience & -0.35 & 0.20 & 1 & & & & & & & & & & & & & \\
\hline 4 & Percentage of foreign sale & 0.32 & 0.00 & 0.02 & 1 & & & & & & & & & & & & \\
\hline 5 & Log of sales & 0.19 & -0.01 & 0.00 & 0.12 & 1 & & & & & & & & & & & \\
\hline 6 & Stock returns (1 year) & -0.01 & 0.01 & 0.01 & 0.01 & -0.06 & 1 & & & & & & & & & & \\
\hline 7 & Return on Assets & 0.00 & -0.04 & -0.06 & -0.02 & 0.10 & 0.16 & 1 & & & & & & & & & \\
\hline 8 & Stock volatility & 0.03 & 0.02 & 0.05 & 0.09 & -0.39 & 0.09 & -0.26 & 1 & & & & & & & & \\
\hline 9 & Leverage & 0.04 & -0.04 & 0.03 & -0.03 & 0.25 & -0.10 & -0.13 & -0.09 & 1 & & & & & & & \\
\hline 10 & Blau Index of Board Diversity (Nationality) & 0.44 & 0.00 & 0.00 & 0.51 & 0.30 & -0.02 & -0.01 & -0.02 & 0.09 & 1 & & & & & & \\
\hline 11 & Log of board size & 0.11 & 0.02 & 0.07 & 0.07 & 0.52 & -0.05 & 0.05 & -0.31 & 0.17 & 0.34 & 1 & & & & & \\
\hline 12 & Non-executive ratio & 0.14 & 0.03 & 0.00 & 0.16 & 0.30 & -0.05 & 0.06 & -0.09 & 0.03 & 0.15 & -0.02 & 1 & & & & \\
\hline 13 & CEO is Chairman & 0.00 & -0.02 & -0.05 & -0.09 & -0.12 & 0.01 & -0.02 & 0.04 & 0.00 & -0.04 & 0.00 & -0.31 & 1 & & & \\
\hline 14 & Log of comp. comm. size & 0.06 & -0.02 & -0.01 & 0.08 & 0.39 & -0.05 & 0.08 & -0.27 & 0.12 & 0.18 & 0.41 & 0.34 & -0.19 & 1 & & \\
\hline 15 & Log of CEO age & 0.07 & -0.01 & -0.04 & 0.15 & 0.13 & -0.04 & 0.01 & -0.16 & 0.02 & 0.07 & 0.16 & 0.02 & 0.05 & 0.11 & 1 & \\
\hline 16 & Log of CEO tenure & -0.10 & 0.00 & -0.03 & -0.01 & -0.08 & 0.06 & 0.10 & -0.10 & -0.12 & -0.08 & 0.03 & -0.04 & -0.04 & 0.01 & 0.27 & 1 \\
\hline
\end{tabular}




\section{Table 3}

CEO foreign experience and total compensation. This table presents the regression results for CEO foreign experience and total compensation with FTSE 350 firms from 1999 to 2015. Variable definitions are provided in Appendix A. Stock return, ROA, leverage and market-to-book ratio are winsorized at the $1^{\text {st }}$ and $99^{\text {th }}$ percentile; robust standard errors in parentheses; $* * *, * *, *$ denote significance at the $1 \%, 5 \%$ and $10 \%$ level, respectively.

\begin{tabular}{|c|c|c|c|}
\hline & \multicolumn{3}{|c|}{ Log of total compensation } \\
\hline & $(\mathbf{1})$ & (2) & (3) \\
\hline Foreign CEO (non-UK) & $\begin{array}{l}0.345 * * * \\
(0.037)\end{array}$ & $\begin{array}{c}0.157 * * * \\
(0.031)\end{array}$ & $\begin{array}{l}0.148 * * \\
(0.064)\end{array}$ \\
\hline National CEO with foreign education & $\begin{array}{c}0.038 \\
(0.038)\end{array}$ & $\begin{array}{c}0.003 \\
(0.030)\end{array}$ & $\begin{array}{c}0.005 \\
(0.048)\end{array}$ \\
\hline National CEO with foreign working experience & $\begin{array}{l}0.167 * * * \\
(0.027)\end{array}$ & $\begin{array}{c}0.099 * * * \\
(0.021)\end{array}$ & $\begin{array}{c}0.045 \\
(0.033)\end{array}$ \\
\hline Percentage of foreign sale & $\begin{array}{c}0.470 * * * \\
(0.046)\end{array}$ & $\begin{array}{c}0.165^{* * *} * \\
(0.038)\end{array}$ & $\begin{array}{c}0.099 * * \\
(0.047)\end{array}$ \\
\hline Percentage of foreign sale * Foreign CEO (non-UK) & & & $\begin{array}{c}0.044 \\
(0.088)\end{array}$ \\
\hline Percentage of foreign sale * National CEO with foreign education & & & $\begin{array}{c}-0.014 \\
(0.089)\end{array}$ \\
\hline $\begin{array}{l}\text { Percentage of foreign sale * National CEO with foreign working } \\
\text { experience }\end{array}$ & & & $0.140^{* *}$ \\
\hline & & & $(0.059)$ \\
\hline Number of product segment & & $\begin{array}{c}0.003 \\
(0.005)\end{array}$ & $\begin{array}{c}0.003 \\
(0.005)\end{array}$ \\
\hline Log of sales & & $\begin{array}{c}0.242 * * * \\
(0.011)\end{array}$ & $\begin{array}{c}0.243 * * * \\
(0.011)\end{array}$ \\
\hline Stock returns (1 year) & & $\begin{array}{c}0.159 * * * \\
(0.024)\end{array}$ & $\begin{array}{l}0.158 * * * \\
(0.024)\end{array}$ \\
\hline ROA & & $\begin{array}{c}0.581 * * * \\
(0.121)\end{array}$ & $\begin{array}{c}0.577 * * * \\
(0.121)\end{array}$ \\
\hline Stock volatility & & $\begin{array}{c}-0.408 * * * \\
(0.126)\end{array}$ & $\begin{array}{c}-0.405 * * * \\
(0.126)\end{array}$ \\
\hline Leverage & & $\begin{array}{l}0.104 * * * \\
(0.035)\end{array}$ & $\begin{array}{c}0.102 * * * \\
(0.035)\end{array}$ \\
\hline Market-to-book ratio & & $\begin{array}{c}0.002 \\
(0.002)\end{array}$ & $\begin{array}{c}0.002 \\
(0.002)\end{array}$ \\
\hline Blau Index of Board Diversity (Nationality) & & $\begin{array}{c}0.298 * * * \\
(0.068)\end{array}$ & $\begin{array}{c}0.291 * * * \\
(0.068)\end{array}$ \\
\hline Log of board size & & $\begin{array}{c}0.463 * * * \\
(0.053)\end{array}$ & $\begin{array}{c}0.463 * * * \\
(0.053)\end{array}$ \\
\hline Non-executive ratio & & $\begin{array}{c}0.652 * * * \\
(0.084)\end{array}$ & $\begin{array}{c}0.648 * * * \\
(0.084)\end{array}$ \\
\hline CEO is Chairman & & $\begin{array}{c}-0.210 * * * \\
(0.028)\end{array}$ & $\begin{array}{c}-0.212 * * * \\
(0.028)\end{array}$ \\
\hline Log of comp. comm. size & & $\begin{array}{c}0.072 * \\
(0.040)\end{array}$ & $\begin{array}{c}0.073^{*} \\
(0.040)\end{array}$ \\
\hline Log of CEO age & & $\begin{array}{c}-0.366^{* * *} * \\
(0.084)\end{array}$ & $\begin{array}{c}-0.362 * * * \\
(0.084)\end{array}$ \\
\hline Log of CEO tenure & & $\begin{array}{c}0.102 * * * \\
(0.011)\end{array}$ & $\begin{array}{c}0.102 * * * \\
(0.011)\end{array}$ \\
\hline Constant & $\begin{array}{c}5.207 * * * \\
(0.072)\end{array}$ & $\begin{array}{c}2.347 * * * \\
(0.353)\end{array}$ & $\begin{array}{c}2.321 * * * \\
(0.353)\end{array}$ \\
\hline Observations & 4727 & 4727 & 4727 \\
\hline Adjusted R-squared & 0.336 & 0.604 & 0.605 \\
\hline Highest VIF & 1.81 & 3.32 & 7.88 \\
\hline Year and Industry dummies & Yes & Yes & Yes \\
\hline
\end{tabular}




\section{Table 4}

Further analysis of CEO foreign experience and total compensation (1). This table presents the regression results for CEO foreign experience and total compensation with FTSE 350 firms from 1999 to 2015. Variable definitions are provided in Appendix A. Stock returns, ROA, leverage and market-to-book ratio are winsorized at the $1^{\text {st }}$ and $99^{\text {th }}$ percentiles. A set of firm-specific economic and corporate governance controls are included but are not reported for simplicity. Robust standard errors in parentheses; ***,**, * denote significance at the $1 \%, 5 \%$ and $10 \%$ level, respectively.

Panel A: 'Foreign CEO (non-UK) without UK experience' equals one if the non-UK CEO does not have any UK experience; 'Foreign CEO (non-UK) with UK education' equals one if the non-UK CEO has UK education; 'Foreign CEO (non-UK) with UK working experience' equals one if the non-UK CEO has UK working experience.

Panel B: 'National CEO with foreign MBA education' equals one if the CEO is British but has a foreign MBA degree; 'National CEO with foreign non-MBA education' equals one if the CEO is British but has a foreign degree but not an MBA.

Panel C: 'National CEO with foreign board role experience' equals one if the CEO is British but has board role experience in a non-UK country; 'National CEO with foreign non-board role experience' equals one if the CEO is British but has non-board role experience in a non-UK country.

\begin{tabular}{|c|c|c|c|}
\hline & \multicolumn{3}{|c|}{ Log of total compensation } \\
\hline & (1) & (2) & (3) \\
\hline \multicolumn{4}{|l|}{ Panel A: Foreign nationality } \\
\hline Foreign CEO (non-UK) & & $\begin{array}{c}0.156 * * * \\
(0.031)\end{array}$ & $\begin{array}{c}0.066 * * \\
(0.032)\end{array}$ \\
\hline Foreign CEO (non-UK) without UK experience & $\begin{array}{c}0.201 * * * \\
(0.035)\end{array}$ & & \\
\hline Foreign CEO (non-UK) with UK education & $\begin{array}{c}-0.161 * \\
(0.093)\end{array}$ & & \\
\hline Foreign CEO (non-UK) with UK working experience & $\begin{array}{c}0.145^{* * *} * \\
(0.055)\end{array}$ & & \\
\hline \multicolumn{4}{|l|}{ Panel B: Foreign education } \\
\hline National CEO with foreign education & $\begin{array}{c}0.002 \\
(0.030)\end{array}$ & & $\begin{array}{c}-0.002 \\
(0.030)\end{array}$ \\
\hline National CEO with foreign MBA education & & $\begin{array}{c}0.036 \\
(0.052)\end{array}$ & \\
\hline National CEO with foreign non-MBA education & & $\begin{array}{l}-0.015 \\
(0.034)\end{array}$ & \\
\hline \multicolumn{4}{|l|}{ Panel C: Foreign working experience } \\
\hline National CEO with foreign working experience & $\begin{array}{c}0.100 * * * \\
(0.021)\end{array}$ & $\begin{array}{c}0.098 * * * \\
(0.021)\end{array}$ & \\
\hline National CEO with foreign board role experience & & & $\begin{array}{c}0.059 * * \\
(0.024)\end{array}$ \\
\hline National CEO with foreign non-board role experience & & & $\begin{array}{c}0.107 * * * \\
(0.021)\end{array}$ \\
\hline Observations & 4727 & 4727 & 4727 \\
\hline Adjusted R-squared & 0.606 & 0.604 & 0.606 \\
\hline Highest VIF & 3.34 & 3.33 & 3.33 \\
\hline Controls & Yes & Yes & Yes \\
\hline Year and industry dummies & Yes & Yes & Yes \\
\hline
\end{tabular}




\section{Table 5}

Further analysis of CEO foreign experience and total compensation (2). This table presents regression results for CEO foreign experience and total compensation with FTSE 350 firms from 1999 to 2015. Variable definitions are provided in Appendix A. 'US CEO' equals one if the CEO is American; 'Non-US foreign CEO' equals one if the CEO is foreign-born but not from the US. Stock returns, ROA, leverage and market-to-book ratio are winsorized at the $1^{\text {st }}$ and $99^{\text {th }}$ percentiles. A set of firm-specific economic and corporate governance controls are included but are not reported for simplicity. Robust standard errors in parentheses; ***, **, * denote significance at the $1 \%, 5 \%$ and $10 \%$ level, respectively.

\begin{tabular}{|c|c|c|c|}
\hline & \multicolumn{3}{|c|}{ Log of total compensation } \\
\hline & (1) & $(2)$ & (3) \\
\hline \multicolumn{4}{|l|}{ Panel A: Foreign nationality } \\
\hline Foreign CEO & & $\begin{array}{c}0.123 * * * \\
(0.036)\end{array}$ & $\begin{array}{c}0.078 * * \\
(0.031)\end{array}$ \\
\hline US CEO & $\begin{array}{c}0.194 * * * \\
(0.047)\end{array}$ & & \\
\hline non-US foreign CEO & $\begin{array}{c}0.141 * * * \\
(0.034)\end{array}$ & & \\
\hline \multicolumn{4}{|l|}{ Panel B: Foreign education } \\
\hline National CEO with foreign education & $\begin{array}{c}0.004 \\
(0.030)\end{array}$ & & $\begin{array}{c}0.003 \\
(0.030)\end{array}$ \\
\hline National CEO with US education & & $\begin{array}{l}0.060^{*} \\
(0.034)\end{array}$ & \\
\hline National CEO with non-US foreign education & & $\begin{array}{c}0.040 \\
(0.032)\end{array}$ & \\
\hline \multicolumn{4}{|l|}{ Panel C: Foreign working experience } \\
\hline National CEO with foreign working experience & $\begin{array}{c}0.100 * * * \\
(0.022)\end{array}$ & $\begin{array}{c}0.095 * * * \\
(0.021)\end{array}$ & \\
\hline National CEO with US working experience & & & $\begin{array}{c}0.116 * * * \\
(0.025)\end{array}$ \\
\hline National CEO with non-US foreign working experience & & & $\begin{array}{c}0.068 * * * \\
(0.025)\end{array}$ \\
\hline Observations & 4727 & 4727 & 4727 \\
\hline Adjusted R-squared & 0.605 & 0.605 & 0.605 \\
\hline Highest VIF & 3.33 & 3.32 & 3.33 \\
\hline Controls & Yes & Yes & Yes \\
\hline Year and industry dummies & Yes & Yes & Yes \\
\hline
\end{tabular}




\section{Table 6}

The determinants of hiring international CEOs. This table presents probit estimates of the determinants of hiring international CEOs with FTSE 350 firms from 2003 to 2011. 'CEO with any type of foreign experience' equals to one if the CEO has any type of foreign experience: nationality, foreign education and/or foreign working experience. Other variable definitions are provided in Appendix A. Stock returns, ROA, leverage and market-tobook ratio are winsorized at the $1^{\text {st }}$ and $99^{\text {th }}$ percentiles. Robust standard errors in parentheses; ***, **, * denote significance at the $1 \%, 5 \%$ and $10 \%$ level, respectively.

CEO with any type of foreign experience 1/0

Blau index of board diversity (nationality) ( $\mathrm{t}-1)$

Log of board size $(\mathrm{t}-1)$

Non-executive ratio $(\mathrm{t}-1)$

Log of comp. comm. size (t-1)

Log of CEO age (t-1)

Log of CEO tenure (t-1)

Constant

Observations

Pseudo R squared

Year and industry dummies
(1)

$0.643 * *$

$0.068 * * *$

(0.014)

$0.104 * * *$

(0.019)

$-1.038 * * *$

(0.242)

$1.468 * * *$

(0.277)

$-0.001$

(0.004)

\section{(2)}

$0.246 * * *$

$0.079 * * *$

(0.015)

0.011

(0.023)

$-0.887 * * *$

(0.248)

$1.231 * * *$

(0.287)

$-0.002$

(0.004)

$1.551 * * *$

(0.156)

$0.417 * * *$

(0.116)

$0.698 * * *$

(0.200)

$-0.318 * * *$

(0.096)

0.052

(0.195)

$-0.059 * * *$

(0.022)

$-1.815^{* * *}$

$-1.981 * *$

(0.560)

(0.949)

3898

3898

0.124

0.153

Yes 


\section{Table 7}

Total compensation of international CEOs vs domestic CEOs (PSM). The table presents the differences in total compensation based on propensity score estimates of international CEO/domestic CEO hiring decision. 'CEO with any type of foreign experience' equals to one if the CEO has any type of foreign experience: nationality, foreign education and/or foreign working experience. The average treatment effect on the treated (ATT) measures the difference between the two groups.

\begin{tabular}{lcccccc}
\hline Variable & Sample & Treated & Controls & Difference & S.E. & T-stat \\
\hline CEO with any type of foreign experience & & & & & \\
Log of total compensation & Unmatched & 7.16 & 6.89 & 0.26 & 0.03 & 8.72 \\
(Treated = 1,190) & ATT & 7.01 & 6.91 & 0.10 & 0.04 & 2.79 \\
\hline
\end{tabular}




\section{Table 8}

Addition robustness tests. This table presents the regression results for CEO foreign experience and total compensation with FTSE 350 firms from 1999 to 2015 with different modelling approaches. Length of foreign working experience equals to the number of years a CEO has spent in working for foreign companies not located in the UK. Other variable definitions are provided in Appendix A. A set of firm-specific economic and corporate governance controls are included but are not reported for simplicity. Robust standard errors in parentheses; $* * *, * *, *$ denote significance at the $1 \%, 5 \%$ and $10 \%$ level, respectively.

Panel A: Lead-lag regression

\section{Log of total compensation}

(1)

(2)

(3)

Foreign CEO (non-UK) (t-1)

$\begin{array}{ccc}0.367 * * * & 0.180 * * * & 0.167 * * \\ (0.041) & (0.035) & (0.073) \\ 0.064 & 0.034 & 0.059 \\ (0.040) & (0.033) & (0.053) \\ 0.149 * * * & 0.078 * * * & 0.002 \\ (0.029) & (0.025) & (0.036) \\ 0.497 * * * & 0.207 * * * & 0.125 * * \\ (0.049) & (0.044) & (0.052) \\ & & 0.059 \\ & & (0.098) \\ & & -0.074 \\ & & (0.105)\end{array}$

Percentage of foreign sale * National CEO with foreign working experience $(\mathrm{t}-1)$

Observations

Adjusted R-squared

Controls

0.336

0.567

0.568

Year and Industry dummies

No Yes Yes

Yes Yes Yes


Panel B: Negative binominal regression

Total compensation (count)

(1)

\begin{tabular}{|c|c|c|c|}
\hline Foreign CEO (non-UK) & $\begin{array}{c}0.400 * * * \\
(0.048)\end{array}$ & $\begin{array}{c}0.162 * * * \\
(0.041)\end{array}$ & $\begin{array}{l}0.154 * \\
(0.089)\end{array}$ \\
\hline National CEO with foreign education & $\begin{array}{c}0.092 \\
(0.059)\end{array}$ & $\begin{array}{c}0.001 \\
(0.050)\end{array}$ & $\begin{array}{l}-0.059 \\
(0.086)\end{array}$ \\
\hline National CEO with foreign working experience & $\begin{array}{l}0.288 * * * \\
(0.037)\end{array}$ & $\begin{array}{l}0.162 * * * \\
(0.032)\end{array}$ & $\begin{array}{c}0.079 \\
(0.050)\end{array}$ \\
\hline Percentage of foreign sale & $\begin{array}{l}0.731 * * * \\
(0.061)\end{array}$ & $\begin{array}{c}0.267 * * * \\
(0.058)\end{array}$ & $\begin{array}{l}0.146 * * \\
(0.072)\end{array}$ \\
\hline Percentage of foreign sale * Foreign CEO (non-UK) & & & $\begin{array}{c}0.064 \\
(0.122)\end{array}$ \\
\hline Percentage of foreign sale * National CEO with foreign education & & & $\begin{array}{c}0.116 \\
(0.158)\end{array}$ \\
\hline $\begin{array}{l}\text { Percentage of foreign sale * National CEO with foreign working } \\
\text { experience }\end{array}$ & & & $\begin{array}{c}0.200 * * \\
(0.090)\end{array}$ \\
\hline Observations & 4727 & 4727 & 4727 \\
\hline Pseudo R2 & 0.097 & 0.192 & 0.192 \\
\hline Controls & No & Yes & Yes \\
\hline Year and Industry dummies & Yes & Yes & Yes \\
\hline
\end{tabular}

Panel C: Quadratic regression

\begin{tabular}{|c|c|c|}
\hline & \multicolumn{2}{|c|}{$\begin{array}{l}\text { Log of total compensation } \\
\text { (1) }\end{array}$} \\
\hline Foreign CEO (non-UK) & $\begin{array}{c}0.107 * * * \\
(0.038)\end{array}$ & $\begin{array}{c}0.034 \\
(0.032)\end{array}$ \\
\hline National CEO with foreign education & $\begin{array}{c}0.008 \\
(0.037)\end{array}$ & $\begin{array}{l}-0.010 \\
(0.030)\end{array}$ \\
\hline Length of foreign working experience & $\begin{array}{l}0.010 * * * \\
(0.002)\end{array}$ & $\begin{array}{l}0.009 * * * \\
(0.002)\end{array}$ \\
\hline Length of foreign working experience (Square) & $\begin{array}{l}0.00006 \\
(0.000)\end{array}$ & $\begin{array}{c}-0.00004 \\
(0.000)\end{array}$ \\
\hline Observations & 4727 & 4727 \\
\hline Adjusted R-squared & 0.359 & 0.610 \\
\hline Controls & No & Yes \\
\hline Year and Industry dummies & Yes & Yes \\
\hline
\end{tabular}




\section{Table 9}

The impact of CEO foreign experience on firm international expansion and performance. This table presents several regression results for the impact of CEO foreign experience on firms' international expansion and performance with FTSE 350 firms from 1999 to 2015. Variable definitions are provided in Appendix A. 'Same region' is an indicator variable equalling one if the CEO has foreign experience in the same region as the region of the foreign sales or acquisitions. Stock returns, ROA, leverage and market-to- book ratio are winsorized at the $1^{\text {st }}$ and $99^{\text {th }}$ percentiles. The acquisition sample is used for regressions on foreign acquisition and firm acquisition performance (both short- and long-term) with 100 per cent stake acquisitions completed by UK firms from 1999 to 2015 . A set of firm-specific economic and corporate governance controls are included but are not reported for simplicity. Robust standard errors in parentheses; ***, **, * denote significance at the $1 \%, 5 \%$ and $10 \%$ level, respectively.

Panel A: Firm foreign activities

\begin{tabular}{|c|c|c|c|c|c|c|}
\hline & \multicolumn{3}{|c|}{ Foreign sales } & \multicolumn{3}{|c|}{ Foreign acquisitions } \\
\hline & (1) & $(2)$ & (3) & $(4)$ & $(5)$ & (6) \\
\hline \multirow[t]{2}{*}{ Foreign CEO (non-UK) } & $0.222 * * *$ & $0.058 * * *$ & 0.016 & $0.201 * * *$ & 0.017 & -0.016 \\
\hline & $(0.012)$ & $(0.013)$ & $(0.018)$ & $(0.032)$ & $(0.037)$ & $(0.039)$ \\
\hline \multirow[t]{2}{*}{ National CEO with foreign education } & 0.018 & -0.002 & $-0.089 * * *$ & $0.060 *$ & 0.024 & $-0.067 * *$ \\
\hline & $(0.014)$ & $(0.012)$ & $(0.015)$ & $(0.033)$ & $(0.032)$ & $(0.031)$ \\
\hline \multirow[t]{2}{*}{ National CEO with foreign working experience } & $0.068 * * *$ & $0.034 * * *$ & $-0.036 * * *$ & $0.074 * * *$ & 0.027 & $-0.112 * * *$ \\
\hline & $(0.010)$ & $(0.009)$ & $(0.010)$ & $(0.024)$ & $(0.025)$ & $(0.024)$ \\
\hline \multirow[t]{2}{*}{ Foreign CEO (non-UK) $*$ Same region } & & & $0.118 * * *$ & & & $0.365^{* * *}$ \\
\hline & & & $(0.019)$ & & & $(0.036)$ \\
\hline \multirow[t]{2}{*}{ National CEO with foreign education * Same region } & & & $0.165 * * *$ & & & $0.282 * * *$ \\
\hline & & & $(0.020)$ & & & $(0.046)$ \\
\hline \multirow[t]{2}{*}{ National CEO with foreign working experience $*$ Same region } & & & $0.156 * * *$ & & & $0.565 * * *$ \\
\hline & & & $(0.012)$ & & & $(0.022)$ \\
\hline Observations & 4727 & 4727 & 4727 & 2176 & 2176 & 2176 \\
\hline Adjusted R-squared" & 0.439 & 0.540 & 0.574 & 0.190 & 0.230 & 0.370 \\
\hline Highest VIF & 1.41 & 3.31 & 3.35 & 1.42 & 3.90 & 3.93 \\
\hline Controls & No & Yes & Yes & No & Yes & Yes \\
\hline Year and Industry dummies & Yes & Yes & Yes & Yes & Yes & Yes \\
\hline
\end{tabular}




\begin{tabular}{|c|c|c|c|c|c|c|}
\hline & \multicolumn{3}{|c|}{$\operatorname{CAR}(-1,+1)$} & \multicolumn{3}{|c|}{$\operatorname{CAR}(-5,+1)$} \\
\hline & (1) & (2) & (3) & (4) & (5) & (6) \\
\hline \multirow[t]{2}{*}{ Foreign CEO (non-UK) } & 0.001 & 0.004 & 0.005 & 0.002 & 0.006 & 0.005 \\
\hline & $(0.003)$ & $(0.004)$ & $(0.004)$ & $(0.004)$ & $(0.005)$ & $(0.005)$ \\
\hline \multirow[t]{2}{*}{ National CEO with foreign education } & -0.002 & -0.001 & -0.002 & -0.001 & 0.000 & 0.000 \\
\hline & $(0.003)$ & $(0.003)$ & $(0.003)$ & $(0.004)$ & $(0.004)$ & $(0.004)$ \\
\hline \multirow[t]{2}{*}{ National CEO with foreign working experience } & 0.003 & 0.004 & 0.002 & $0.006^{*}$ & $0.007 * *$ & 0.005 \\
\hline & $(0.002)$ & $(0.003)$ & $(0.003)$ & $(0.003)$ & $(0.003)$ & $(0.004)$ \\
\hline \multirow[t]{2}{*}{ Cultural Distance Index } & & -0.003 & -0.004 & & -0.001 & -0.002 \\
\hline & & $(0.004)$ & $(0.004)$ & & $(0.006)$ & $(0.006)$ \\
\hline \multirow[t]{2}{*}{$\mathrm{CDI} *$ Foreign CEO (non-UK) } & & & -0.001 & & & 0.002 \\
\hline & & & $(0.003)$ & & & $(0.004)$ \\
\hline \multirow[t]{2}{*}{ CDI * National CEO with foreign education } & & & 0.002 & & & -0.000 \\
\hline & & & $(0.004)$ & & & $(0.005)$ \\
\hline \multirow[t]{2}{*}{ CDI * National CEO with foreign working experience } & & & $0.004 * *$ & & & $0.005 *$ \\
\hline & & & $(0.002)$ & & & $(0.002)$ \\
\hline Observations & 2176 & 2176 & 2176 & 2176 & 2176 & 2176 \\
\hline Adjusted R-squared & 0.014 & 0.043 & 0.045 & 0.014 & 0.025 & 0.026 \\
\hline Highest VIF & 1.42 & 9.68 & 9.82 & 1.42 & 9.68 & 9.82 \\
\hline Controls & No & Yes & Yes & No & Yes & Yes \\
\hline Year and Industry dummies & Yes & Yes & Yes & Yes & Yes & Yes \\
\hline
\end{tabular}

